（様式・終了-1）

\title{
公開資料
}

\section{研究開発成果実装支援プログラム 実装活動の名称}

「家庭内児童虐待防止にむけたヒューマン・サービスの社会実装」

実装支援プロジェクト終了報告書

実装期間 平成 21 年 9 月 平成 24 年 9 月

実装機関名 立命館大学

実装責任者

氏 名 中村 正 


\section{I 実装活動の名称と目標、3 年間の活動要約 (1) 実装活動の名称}

家庭内児童虐待防止にむけたヒューマン・サービスの社会実装

\section{(2)最終目標}

第 1 は虐待ゼロ制度モデルの構築、第 2 は連携の仕組みの開発、第 3 は臨床理論の構 築と人材育成の仕組みの創出である。虐待する家族一の家族再統合計画の組み立て、グ ループワークや個人と夫婦へのカウンセリング、合同家族面接という統合されたファミ リーカウンセリングの実施、児童相談所としてのケースワーク、当該家族にかかわる多 職種連携会議の実施、家族再統合後の家族支援という一連の流れをつくり、家族システ 厶変容を支えることがこのプログラムの内容である。そしてそれらを支える家族臨床理 論を構築する。プログラムを実装する連携先として大阪市と大阪府を想定している。こ のフレームはどの地域でも応用可能である。この実装をもとにした援助理論モデルと一 連の仕組みによる実践を研修内容として編み上げ、それを人材育成へと精緻化すること により児童相談所での家族支援として標準的に実装可能なものとなるような取り組み とする。

\section{(3) 支援期間終了後の目標（到達点）}

最終目標の実現のために、(1)大阪府内全域を対象として実装すること、(2)本プログラム を継続して実施できる人材育成、そして(3)研修の仕組みの構築とそのために必要な資材の 準備、(4)これらを統一したマネジメントのもとに実施することを支える臨床家族理論の構 築を到達目標とする。

\section{（4）3年間の活動実績（要約）}

月 2 回、一回 2 時間の虐待した父親向けのグループワーク（男親塾と命名）を大阪市内で開 催している。この親支援は各児童相談所が計画した、虐待介入後の家族再統合プログラムのな かに組み込まれている。虐待された子どもの生活と心理面でのケアを基本（子どもの最善の利 益の実現）として虐待家族支援のやり直し支援のためのきずな再構成ケースワークをよりよく 機能させるために、このプログラムは効果をもつ。この援助モデルはこれまで十全ではなかっ た親対応の選択肢として意味があり、当該家族システムの健康度を高めるためにも脱暴力の課 
題はきわめて重要であるという臨床家族理論をもとにしている。そのために、当該家族にかか わる多職種連携会議を適宜開催した。また、人材育成は年 2 回の事例検討会を定例化し、担当 者が事例報告を行い、研究者がスーパーバイズを並行しておこなう形態での家族再統合実践検 討会とした。さらにこの家族支援を体系化した本プロジェクトのプロモーション用DVDを作 成し、各児童相談所に配布した。プログラムの実装先も大阪府内一円に拡大され、近隣府県は もちろんのこと全国規模での研修会を主催し、各地で応用展開可能なプログラムとする努力を おこなった。とくに青森県むつ市児童相談所ではプログラムの専門家向け講座を開催した。プ ログラム全体をとおしてマネジメントする総合的な能力が要請されるので連携先の自治体の担 当者とは緊密な情報交換を欠かさず、さらにグループワークを指導できる若手の育成のために 臨床心理士 2 名を継続的に参加させている。これらを支える統合された臨床家族理論について はイギリスの調査による知見をも加味した論文と口頭発表をとおして構築してきた。

\section{II 実装活動の計画と実装活動}

\section{(1) 全体計画}

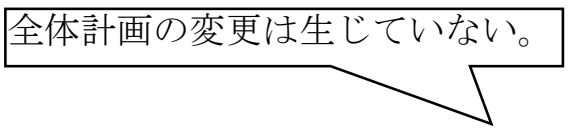

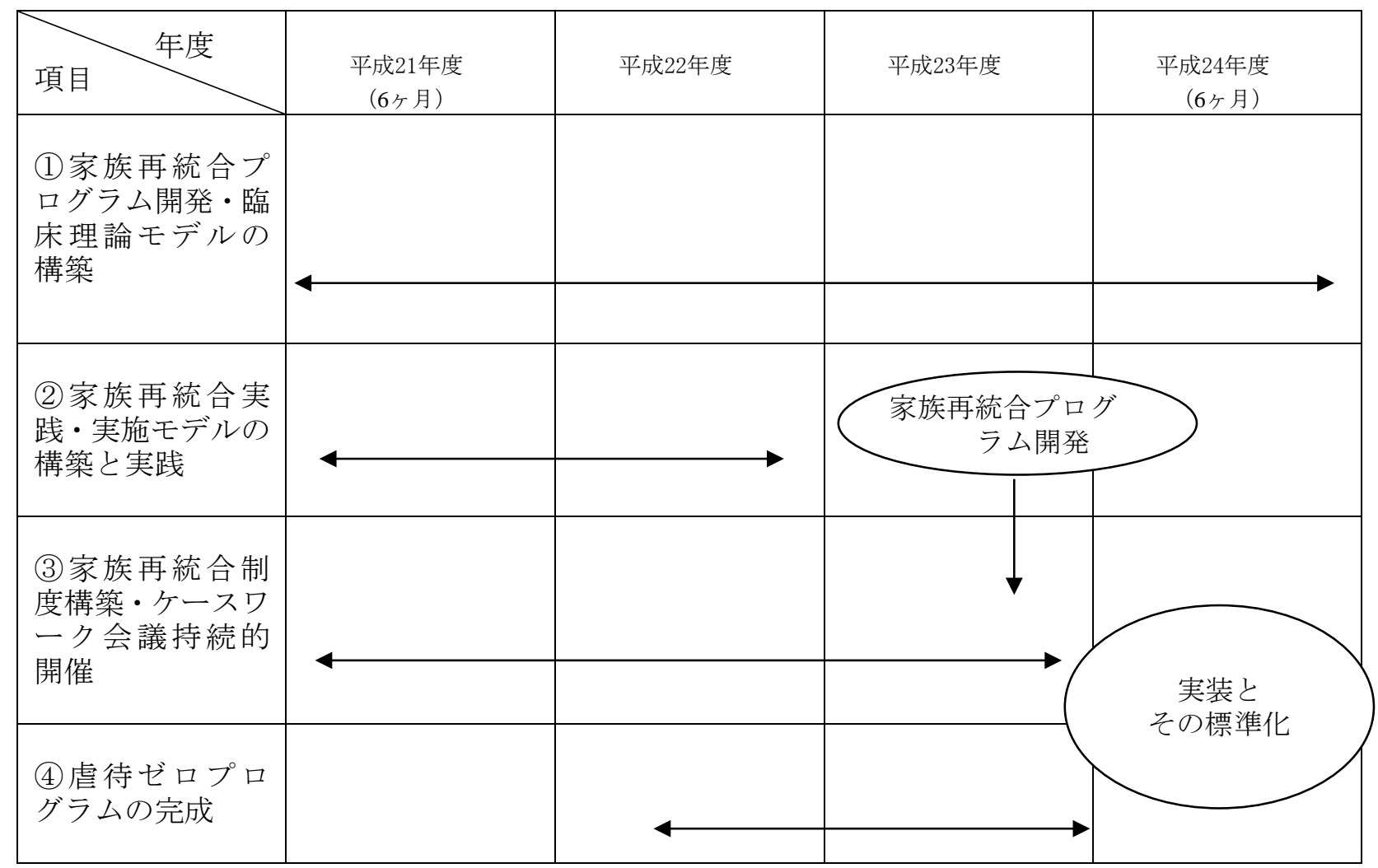




\section{（2）各年度の実装活動の具体的内容}

\section{平成 21 年度}

虐待親向けのプログラムを実施した。月 2 回のグループワークと月 2 回の個人カウンセ リングもしくは夫婦カウンセリング、そして参加している家族を対象にしたケース会議を 展開した。グループワークは月に 2 回で 2009 年10月から 2010 年 3 月までに計12回、カウン セリングは、15回セッション実施した。第 2 は、特定の家族をめぐる多職種連携会議を実 施したことである。児童養護施設の心理士（きょうだいなので 2 名）と施設でのケア担当 者、児童相談所の精神科医と心理士、統括する主任児童福祉司、プレイセラピー担当の心 理士等、総数 12 名のケースカンファレンスをおこないケース分析を実施した。家族の再生 にむけた実りの多いものであった。第 3 は、申請書に記載した目標であるヒューマン・サ ービス社会技術の応用に関して、近隣自治体との協議を開始した。大阪府児童相談所、大 阪府堺市児童相談所（政令市）の 2 自治体である。個人情報保護の規定、委託契約等、実 現準備を開始した。第 4 は、人材育成に関して、虐待親向けプログラムのコアの一種であ るソーシャルスキルトレーニングについて児童相談に関係する援助職者向けの基礎訓練 をワークショップ方式で実施した。2010年3月13日－14日にかけて立命館大学大阪オフィ スで開催し、20名が参加した。

\section{平成 22 年度}

家族再統合実践を継続した。「男親塾」と称した虐待父親向けのプログラムである。成 果の第 1 は、虐待事例の問題域の広がりが見られた。具体的には、月 2 回のグループワー クと月 2 回の個人カウンセリングもしくは夫婦カウンセリング、そして参加している家族 を対象にして心理、医学、福祉の担当者があつまるケース会議を適宜開催した。グループ ワークは月に 2 回を基本とした。2010年4月から2011年3月までに計24回、カウンセリング は、16回のセッションを実施した。第 2 は、人材育成に関して大規模な臨床家族理論の構 築にむけたシンポジウムを開催した（2010年12月12日、100名の参加があった）。児童相 談所の内外から関係者を集め、家族再統合の多元的な展開についてケースマネジメント、 スキルの組み込み方、虐待家族の関係性の詳細分析、子どもの意見聴取の法 - 心理的イン タビュー手法開発など新しいテーマに取り組んだ。再統合のための社会技術というまとめ 方の内実がみえてきたといえる。第 3 は、当初の申請書に記載した目標である近隣自治体 への拡大について今年度より大阪府（５ヶ所）と堺市（政令市）に拡大寸ることができた。 この結果、大阪府内全域を対象にすることができている。くわえて、個人情報保護に関す る誓約書、研究協力承諾書、本人との契約書等を準備し、受け入れを開始した。実績の第 
4 は、とくに困難な再統合となる性虐待の家族に関しても対応を開始したことである。か ねてよりニーズはあったが面談にまでケースワークできたことは大きい。この事例はグル ープワークヘの参加を促進させるが当面は個人対応として大阪府の児童相談所（中央）で のカウンセリング対応としている。2011年 1 月から 3 月にかけて 3 回のセッションを実施 した。虐待親の対象が広がったことは家族再統合の質を深めていくことになる。多問題家 族への対応の手がかりができたといえる。実績の第 5 は、さらに対象地域を広げるべく、 近畿児童相談所の研修会 (2010年9月に大阪市で実施)を大規模に開催した。この研修会に おいて特筆すべきは虐待した父親の参加を得て、こうした取り組みの必要性を当事者から 報告できた。当事者参加型のプログラム開発は対人社会サービスとしてのヒューマン・サ ービスを社会実装する際に有意義である。コストと効果、プログラムコンテンツ開発、動 機形成とその維持、専門家へのインパクトなどの諸点からその有意義な点が確認できると 想定している。さらにニーズのある家族の拡大もみられた。性虐待対応が 2 件、刑事事件 事例（傷害致死事例と傷害事例の計 2 件）があった。

\section{平成23年度}

当初の計画どおり家族再統合実践を展開した。第 1 は継続して虐待親向けのプログラム を実施した。原則として月 2 回のグループワークと月 2 回の個人カウンセリングもしくは 夫婦カウンセリング、そして参加している家族を対象にしたファミリーグループ・カンフ アレンスの定期的かつ持続的な開催である。グループワークは月に 2 回を基本とした。20 11年 4 月から 2012 年 2 月までに計 22 回、カウンセリングは 15 回のセッションを実施した。 ファミリーグループ・カンファレンスは家族再統合がす寸む一家族に対して合計 3 回実施 した。第 2 は、家族再統合実践についての児童相談所・児童福祉施設など子どもの福祉現 場で働く職員の専門性を高める取り組みを重点的に実施した。これは当初計画の重点目標 として掲げていた課題である。(1)「児童相談所とその近接領域における家族療法・家族援 助研修会」（2012年2月4-5日、広島県安芸グランドホテル、150名の児童相談所の心理職 と福祉職等の参加があった）で研修を実施した。家族療法の技法とその考え方についてシ ンポジウムでこの実装の取り組みと理論を伝えた。とくに暴力のある家族システムに介入 する際の重要ポイントを伝えた。(2) 1 日もしくは 2 日連続の支援者支援研修を 5 回実施し た。これらは複雑化する児童福祉現場に対応できる人材の育成の課題に応えるものであり、 職員のスキルを向上するとともに、バーンアウト防止に資することができた。第 3 は事例 検討会の開催である。実装プログラムをとおして関与する家族の再統合の諸過程の詳細に ついて大阪府と大阪市の児童相談所の虐待ケースを対応する職員に公開して検討会を開 催した。一回目は大阪市児童相談所（大阪市）、2 回目は大阪府児童相談所（中央・寝屋 川市）でそれぞれ 2 事例、合計 4 事例をとりあげ、担当者がケースワークの過程を紹介し 
中村が解説するという形態です寸めた。これは再統合の実際の理解についてとともに男親 塾への参加を促すことにおいても効果的であった。第 4 は男親塾への参加層が対象地域を 拡大したことである。事例としても傷害や傷害致死事例、性虐待親事例や多問題家族事例

（妻の精神障碍や妻のギャンブル依存が重なる事例）が増え、再統合に向けたケースワー クの質の向上が求められることとなった。課題としては難度が高く、挑戦的な課題を扱う こととなった。さらに、英国の類似の取り組みの調查と検討を行い、社会的養護の充実と して里親やグループホームの充実に向けての厚生労働省の提案がなされたことともかか わり、本プログラムのメンバーは複数の団体との連携を進めてきた。これも継続した場合 の重点課題としたい。

\section{平成24年度}

大阪市の難事例ケースの家族について再統合を可能にできた。 5 年間の子どもの保護の 後の再統合である。本プログラムのエキスがすべて包摂された難事例であったので、この ケースワークが成功裏にす寸んできたことは児童相談所の家族支援の力量向上の指標と もいえる。4月以降も継続した再統合後支援を続けている。最終年度にあたり、人材育成 と研修のための本プログラムプロモーション用のD V Dを作成した。その収録もかねて、 家族支援者の力量向上の継続的な研修会を組織した。また、プログラムの普及のために青 森県むつ市児童相談所と連携した家族理解ワークショップを開催した（2012年9月7日）。 この期もまた、継続して月 2 回のグループワークと大阪市と大阪府において月 1 回の個別 面談、夫婦面談、定例となっている事例研修会を1回開催した。

\section{IIII実装支援活動の成果}

\section{(1) 目標達成及び実装状況}

\begin{tabular}{|c|c|}
\hline $\begin{array}{l}\text { 【支援期間終了後の目標 (到達点)】 } \\
\text { 大阪市と大阪府内での実装をめざす } \\
\end{array}$ & $\begin{array}{l}\text { 【実装状況】 } \\
\text { 大阪市、大阪府内五力所と政令市である堺市に }\end{array}$ \\
\hline & $\begin{array}{l}\text { で本プログラムが作動していることになる。虐待 } \\
\text { 家族全体を捕捉することは闍題の性格上困難で } \\
\text { あるが、ニーズのある家族全体の } 10 \% \text { 程度を対象 } \\
\text { にできた。さらに近隣府県の拡大の可能性につい } \\
\text { ては近畿レベルの児童相談所での研修を行い、普 } \\
\text { 及のため本プログラムブロモいションD V D } \\
\text { を作成したのでとれらをもとに拡大していくこ } \\
\text { ととする。 }\end{array}$ \\
\hline
\end{tabular}




\section{（2）実装された成果の今後の自立的継続性}

すでに大阪府内の児童相談所では本プログラムにもとづく虐待家族対応について今年度計画 に組み込まれている。心理士と福祉司向けの研修会も予定されている。家族再統合計画は家庭 裁判所の措置の判断が2力年継続なので実装の継続は前提となっている。

\section{（3）実装活動の他地域への普及可能性}

すでに大阪市から大阪府内へと実装は拡大した。近畿の各児童相談所向けの研修も実施し、 全国規模での研修会も開催し、さらに青森県むつ市児童相談所ではワークショップも開催して いるので当該地域での人材育成とかかわり普及の可能性は大きい。

\section{（4）実装活動の社会的副次成果}

高齢者虐待という他の家族問題に拡大していく可能性を得つつある。とりわけ大阪市内のケ アマネジャーたちが関心を寄せており2012年度後半に研修会を予定している。

\section{(5) 人材育成}

虐待親支援に取り組むことができるグループワークカを身につける目的で男親塾には常に2 名の若手の臨床心理士を補助として入れている。また、児童相談所に勤務する心理士と福祉司 むけの研修会は年2回定期化した。

\section{（6）実装活動で遭遇した問題とその解決策}

実装地域が拡大したことによる連絡体制の再構築が課題となったが、府内組織の担当者を一 元化することにより解決できた。 


\section{IV 実装活動の組織体制}

（1）体制

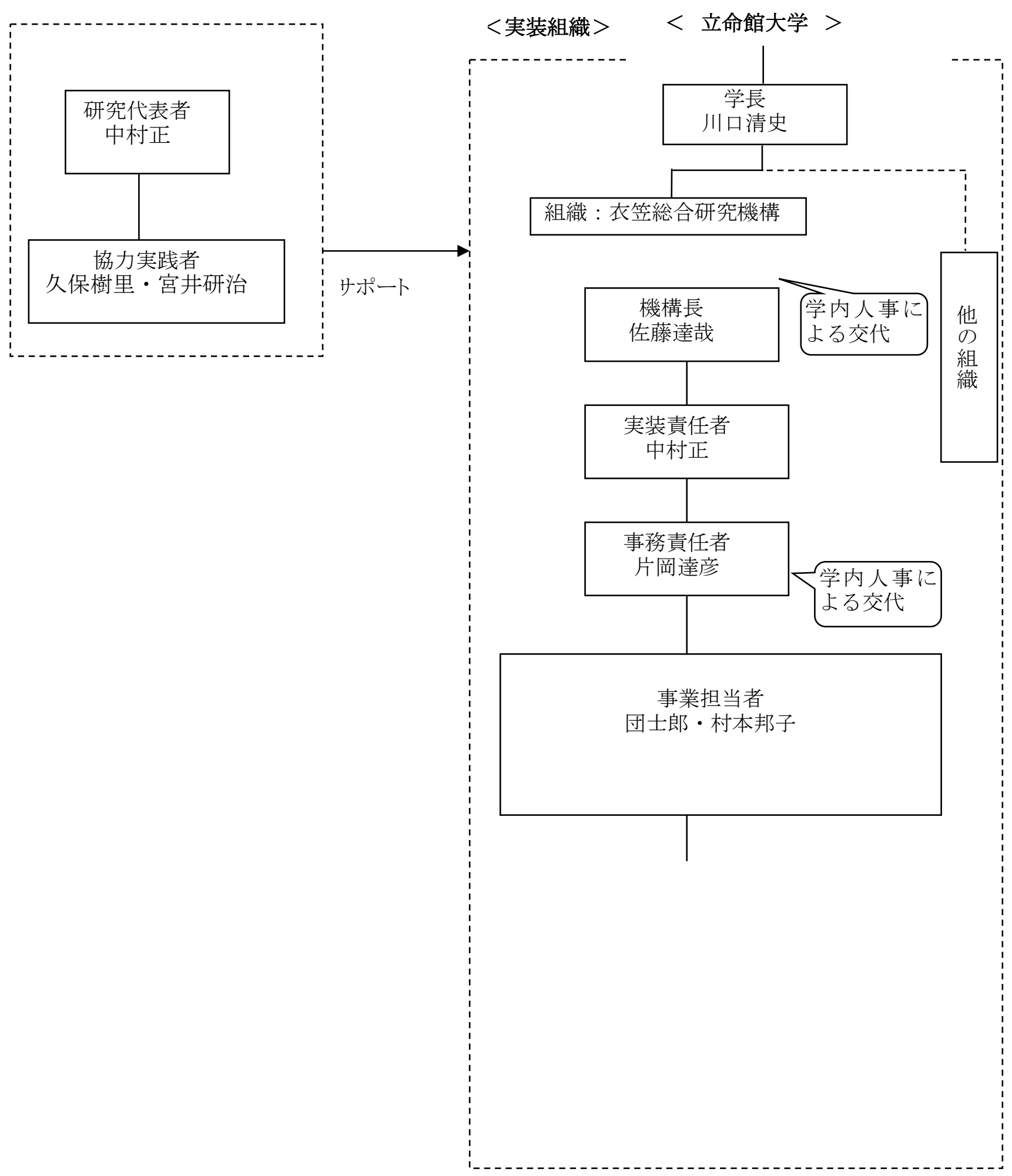




\section{$\mathrm{V} \quad$ 理解普及のための活動とその評価}

(1) 展示会への出展等

\begin{tabular}{|c|c|c|c|c|c|}
\hline 年月日 & 名称 & 場所 & 概要 & $\begin{array}{l}\text { ステーク } \\
\text { ホルダー }\end{array}$ & $\begin{array}{l}\text { 社会的 } \\
\text { インパ } \\
\text { クト }\end{array}$ \\
\hline $\begin{array}{l}2012 \text { 年 } 9 \\
\text { 月 } 3 \text { 日〜 } \\
9 \text { 月 } 9 \text { 日 }\end{array}$ & $\begin{array}{l}\text { 東日本・家族応援プ } \\
\text { ロジェクト } \\
\text { むつ } 201012\end{array}$ & $\begin{array}{l}\text { むつ市図書館展 } \\
\text { 示ホール（青森 } \\
\text { 県） }\end{array}$ & $\begin{array}{l}\text { 立命館大学教授であり、マ } \\
\text { ンガ「家族の練習問題」の } \\
\text { 著者でもある団士郎による } \\
\text { 漫画をパネル展示 }\end{array}$ & $\begin{array}{l}\text { こどもを } \\
\text { 持つ親、 } \\
\text { 家族支援 } \\
\text { 者 }\end{array}$ & $\begin{array}{l}\text { 漫 画媒 } \\
\text { 体 の 効 } \\
\text { 果は大 }\end{array}$ \\
\hline
\end{tabular}

\section{(2) 研修会、講習会、観察会、贸談会、シンポジウム等}

\begin{tabular}{|c|c|c|c|c|c|}
\hline 年月日 & 名称 & 場所 & 概要 & $\begin{array}{l}\text { ステーク } \\
\text { ホルダー }\end{array}$ & $\begin{array}{l}\text { 社会的 } \\
\text { インパ } \\
\text { クト }\end{array}$ \\
\hline $\begin{array}{l}2009 \text { 年 } \\
10 \text { 月 } 10 \\
\text { 日 } ~ \\
2012 \text { 年 } 9 \\
\text { 月 } 29 \text { 日 } \\
\text { (全 } 68 \\
\text { 回) }\end{array}$ & 男親塾 & $\begin{array}{l}\text { クレオ大阪中央 } \\
\text { (大阪男女共同 } \\
\text { 参画センター中 } \\
\text { 央館) }\end{array}$ & $\begin{array}{c}\text { 父親の子育てについて、男 } \\
\text { 親で話し合うグループ講座 } \\
\text { (参加人数のベ約 } 400 \text { 名) }\end{array}$ & $\begin{array}{l}\text { 虐待する } \\
\text { 父親 }\end{array}$ & $\begin{array}{l}\text { 基幹と } \\
\text { なって } \\
\text { 定着し、 } \\
\text { 認知度 } \\
\text { 高い }\end{array}$ \\
\hline $\begin{array}{l}2010 \text { 年 } 3 \\
\text { 月 } 13,14 \\
\text { 日 }\end{array}$ & $\begin{array}{l}\text { SST ワークショップ } \\
\text { (ソーシャル・スキ } \\
\text { ル・トレーニング) } \\
\text { 「こどもの問題行 } \\
\text { 動に有効なかかかわ } \\
\text { り方を学ぼう」 }\end{array}$ & $\begin{array}{l}\text { 立命館大学アカ } \\
\text { デメイア (大阪) }\end{array}$ & $\begin{array}{l}\text { SST の基礎理論並びに演習 } \\
\text { に関する研修会 } \\
\text { (参加人数約 } 20 \text { 名) }\end{array}$ & $\begin{array}{l}\text { 家族支援 } \\
\text { 当事者 }\end{array}$ & $\begin{array}{l}\text { 対人援 } \\
\text { 助技術 } \\
\text { の基本 } \\
\text { として } \\
\text { 必須 }\end{array}$ \\
\hline $\begin{array}{l}2010 \text { 年 } \\
12 \text { 月 } 12 \\
\text { 日 }\end{array}$ & $\begin{array}{l}\text { 公開シンポジウム } \\
\text { 「家庭内暴力をの } \\
\text { こえる「家族臨床 } \\
\text { 理論」の構築にむけ } \\
\text { て } \\
\text { 一虐待を解決する } \\
\text { 取り組みの最前線 } \\
\text { からの問題提起一」 }\end{array}$ & $\begin{array}{l}\text { 立命館大学アカ } \\
\text { デメイア (大阪) }\end{array}$ & 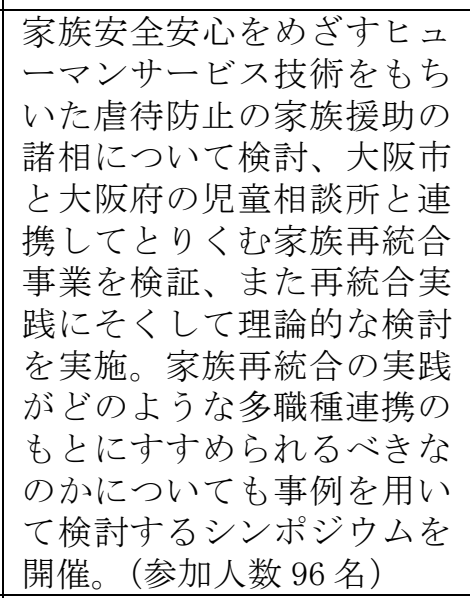 & $\begin{array}{l}\text { 児童相談 } \\
\text { 所、臨床 } \\
\text { 心理士、 } \\
\text { カウンセ } \\
\text { ラーなど } \\
\text { 家族支援 } \\
\text { 当事者、 } \\
\text { また支援 } \\
\text { を受ける } \\
\text { 側 }\end{array}$ & $\begin{array}{l}\text { 満席と } \\
\text { なり連 } \\
\text { 携の場 } \\
\text { として } \\
\text { 機能し } \\
\text { た }\end{array}$ \\
\hline $\begin{array}{l}2011 \text { 年 } 1 \\
\text { 月 } 15,16 \\
\text { 日 }\end{array}$ & $\begin{array}{l}\text { 効果的なケース会 } \\
\text { 議の進め方 }\end{array}$ & $\begin{array}{l}\text { 大阪市子育てい } \\
\text { ろいろ相談セン } \\
\text { ター }\end{array}$ & $\begin{array}{l}\text { 家族支援の現場で開催され } \\
\text { る早会議の進行 } \\
\text { を学ぶ支援者の研修会。議 } \\
\text { 論を可視化しがら効果的 } \\
\text { に進める「ホワイトボー } \\
\text { ド・ミーティング」の進行 } \\
\text { 役に必要なファシリテーシ } \\
\text { ヨンを学ぶ。また共有した } \\
\text { 情報から家族の状況を見立 } \\
\text { て、必要な支援につなげる } \\
\text { 「アセスメンの視点を } \\
\text { 身につけることが目的 } \\
\text { (参加人数約 } 40 \text { 名) }\end{array}$ & $\begin{array}{l}\text { 家族支援 } \\
\text { 当事者 }\end{array}$ & $\begin{array}{l}\text { 対人援 } \\
\text { 助技術 } \\
\text { の必須 } \\
\text { として } \\
\text { 定着 }\end{array}$ \\
\hline $\begin{array}{l}2011 \text { 年 } 2 \\
\text { 月 } 11 \text { 日 } \\
\end{array}$ & $\begin{array}{l}\text { アタッチメント（愛 } \\
\text { 着） に基づく関係 }\end{array}$ & ヴィアーレ大阪 & $\begin{array}{l}\text { 愛着障害・愛着不全など、 } \\
\text { 最近、「愛着」という概念が }\end{array}$ & $\begin{array}{l}\text { 家族支援 } \\
\text { 当事者 }\end{array}$ & $\begin{array}{l}\text { 臨床家 } \\
\text { 族理論 }\end{array}$ \\
\hline
\end{tabular}




\begin{tabular}{|c|c|c|c|c|c|}
\hline & $\begin{array}{l}\text { 性の評価と介入の } \\
\text { ヒントーサーク } \\
\text { ル・オブ・セキュリ } \\
\text { ティーフログラム } \\
\text { の紹介— }\end{array}$ & & 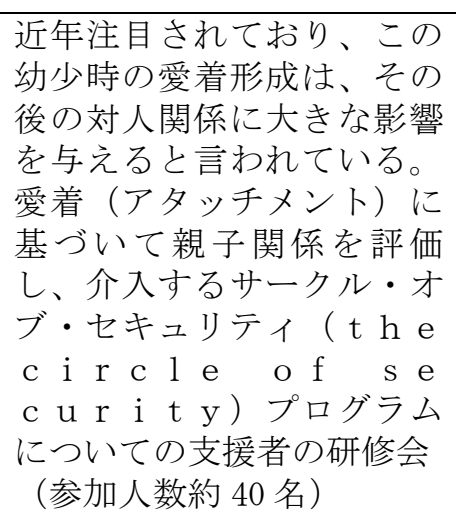 & & $\begin{array}{l}\text { の基本 } \\
\text { の理解 } \\
\text { として } \\
\text { 好評を } \\
\text { 得た }\end{array}$ \\
\hline $\begin{array}{l}2011 \text { 年 } 9 \\
\text { 月 } 24 \text { 日 }\end{array}$ & $\begin{array}{l}\text { 虐待とアタッチメ } \\
\text { ント(愛着) }\end{array}$ & $\begin{array}{l}\text { クレオ大阪西 } \\
\text { 大阪市立男女共 } \\
\text { 同参画センター } \\
\text { 西部館 }\end{array}$ & $\begin{array}{l}\text { 被虐待児に関わる現場にい } \\
\text { る支援者に対して、攵じも } \\
\text { の育ちを促進していくため } \\
\text { のアタッチメン理論と実 } \\
\text { 践方法についての研修会 } \\
\text { (参加人数 } 87 \text { 名) }\end{array}$ & $\begin{array}{l}\text { 家族支援 } \\
\text { 当事者 }\end{array}$ & 同上 \\
\hline $\begin{array}{l}2011 \text { 年 } \\
11 \text { 月 } 5,6 \\
\text { 日 }\end{array}$ & $\begin{array}{l}\text { ABA（応用行動分析） } \\
\text { ワークショップ }\end{array}$ & $\begin{array}{l}\text { 大阪市阿倍野市 } \\
\text { 民学習センター }\end{array}$ & $\begin{array}{l}\text { ABA ( Applied Behavior } \\
\text { Analysis):応用行動分析理 } \\
\text { 論に基づいた総合行動教育 } \\
\text { サービス } 2 \text { 日間のワークシ } \\
\text { ヨップ } \\
\text { (参加人数約 } 70 \text { 名) }\end{array}$ & $\begin{array}{l}\text { 家族支援 } \\
\text { 当事者 }\end{array}$ & 同上 \\
\hline $\begin{array}{l}2012 \text { 年 } 1 \\
\text { 月 } 14,15 \\
\text { 日 }\end{array}$ & $\begin{array}{l}\text { 児童相談所はなぜ } \\
\text { しんどいのか〜ど } \\
\text { うて行けばいい } \\
\text { のか〜 } \\
\text { 一児童相談の歴史 } \\
\text { と制度からー- }\end{array}$ & $\begin{array}{l}\text { 立命館大学大阪 } \\
\text { キャンパス }\end{array}$ & 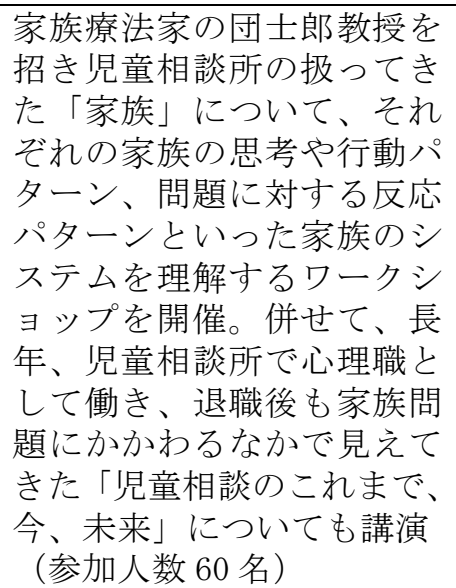 & $\begin{array}{l}\text { 家族支援 } \\
\text { 当事者 }\end{array}$ & $\begin{array}{l}\text { 家族ジ } \\
\text { エノグ } \\
\text { ラムも } \\
\text { 支援者 } \\
\text { 必須と } \\
\text { て定 } \\
\text { 着 }\end{array}$ \\
\hline $\begin{array}{l}2012 \text { 年 } 2 \\
\text { 月 } 18,19 \\
\text { 日 }\end{array}$ & $\begin{array}{l}\text { スターペアレンテ } \\
\text { イング講座 }\end{array}$ & ドーンセンター & $\begin{array}{l}\text { 親学習プログラムについて } \\
\text { 学ぶ支援者研修会。「スタ } \\
\text { ・ペアレンティン゙は } \\
\text { 親も自分を大切にしなが } \\
\text { ら、たたかず、やかさず、 } \\
\text { 楽しみながら子育てをする } \\
\text { ための技法であり、親子間、 } \\
\text { 子ども同士などで起こる問 } \\
\text { 題を解決するプログラム。 } \\
\text { 子どもの年齢や発達段階や } \\
\text { 気質にあわせて際 } \\
\text { の場面の状況や親と子の感 } \\
\text { 情に合わせて、スター・ベ } \\
\text { アレンティングの具体的な } \\
\text { スキルを駆使して対処する } \\
\text { 方法を学ぶ。 } \\
\text { (参加人数 } 50 \text { 名) }\end{array}$ & $\begin{array}{l}\text { 家族支援 } \\
\text { 当事者 }\end{array}$ & $\begin{array}{l}\text { 親支援 } \\
\text { の王道 } \\
\text { として } \\
\text { 好評 }\end{array}$ \\
\hline $\begin{array}{l}2012 \text { 年 } 3 \\
\text { 月 } 3 \text { 日 }\end{array}$ & $\begin{array}{l}\text { こどもの現場の変 } \\
\text { え方! }\end{array}$ & $\begin{array}{l}\text { 子育ていろいろ } \\
\text { 相談センター }\end{array}$ & $\begin{array}{l}\text { 子どもに安心で安全な環境 } \\
\text { を提供することに関する支 } \\
\text { 援者の研修会 }\end{array}$ & $\begin{array}{l}\text { 家族支援 } \\
\text { 当事者 }\end{array}$ & $\begin{array}{l}\text { 子ども } \\
\text { の視点 } \\
\text { の獲得 }\end{array}$ \\
\hline
\end{tabular}




\begin{tabular}{|c|c|c|c|c|c|}
\hline & & & (参加人数 41 名) & & \\
\hline $\begin{array}{l}2012 \text { 年 } 7 \\
\text { 月 } 22 \text { 日 }\end{array}$ & $\begin{array}{l}\text { ジェノグラムと家 } \\
\text { 族造形法一家族を } \\
\text { 理解するための実 } \\
\text { 践的事例検討法一 }\end{array}$ & $\begin{array}{l}\text { 城北市民学習セ } \\
\text { ンター }\end{array}$ & 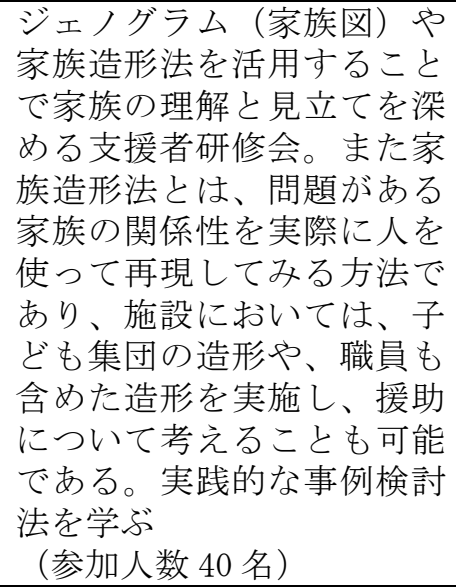 & $\begin{array}{l}\text { 家族支援 } \\
\text { 者 }\end{array}$ & $\begin{array}{l}\text { ジェノ } \\
\text { グラム } \\
\text { は必須 } \\
\text { なの馀 } \\
\text { 反復し } \\
\text { て研修。 } \\
\text { ニーズ } \\
\text { は高い }\end{array}$ \\
\hline $\begin{array}{l}2012 \text { 年 } 8 \\
\text { 月 } 4 \text { 日 }\end{array}$ & $\begin{array}{l}\mathrm{D} \mathrm{V} \text { 被害者サポー } \\
\text { ター養成講座 } \\
\text { 暴力つついて男 } \\
\text { 性加害者への脱暴 } \\
\text { 力支援 }\end{array}$ & $\begin{array}{l}\text { 高梁総合文化会 } \\
\text { 館 }\end{array}$ & $\begin{array}{l}\mathrm{D} \text { V 被害者のサポーター養 } \\
\text { 成の為の研修講座 }\end{array}$ & $\begin{array}{l}\text { 家族支援 } \\
\text { 者 }\end{array}$ & $\begin{array}{l}\text { 他府県 } \\
\text { 響 }\end{array}$ \\
\hline $\begin{array}{l}2012 \text { 年 } 8 \\
\text { 月 } 4 \text { 日 }\end{array}$ & $\begin{array}{l}\text { 一ベン・ファーマン } \\
\text { 先生のソリューシ } \\
\text { ヨン・フォーカス・ } \\
\text { アプローチ入門一 } \\
\text { 子どもを! 現場 } \\
\text { を! 元気にする }\end{array}$ & $\begin{array}{l}\text { 大阪市立子育て } \\
\text { いろいろ相談セ } \\
\text { ンター }\end{array}$ & $\begin{array}{l}\text { フィンランドからベン・フ } \\
\text { アーマン講師を招き、氏の } \\
\text { 開発したソリューショ・解決志向)・ア } \\
\text { フォーカス } \\
\text { プローチを活用して、子ど } \\
\text { もたちの問題行動に子ども } \\
\text { が自ら主体的に動いて問題 } \\
\text { 解決できるようになるをと } \\
\text { を応援するプログラムを学 } \\
\text { ぶ支援者の研修会。 } \\
\text { (参加人数 } 68 \text { 名) }\end{array}$ & $\begin{array}{l}\text { 家族支援 } \\
\text { 者 }\end{array}$ & $\begin{array}{l}\text { 問題解 } \\
\text { 決手法 } \\
\text { も必須 } \\
\text { 技術な } \\
\text { ので好 } \\
\text { 評 }\end{array}$ \\
\hline $\begin{array}{l}2012 \text { 年 } 8 \\
\text { 月 } 5 \text { 日 }\end{array}$ & $\begin{array}{l}\text { 一ベン・ファーマン } \\
\text { 先生のソリューシ } \\
\text { ヨン・フォーカス・ } \\
\text { アプローチ入門一 } \\
\text { 応用編 解決志向 } \\
\text { を現場で活用しよ } \\
う\end{array}$ & $\begin{array}{l}\text { 大阪市立子育て } \\
\text { いろいろ相談セ } \\
\text { ンター }\end{array}$ & 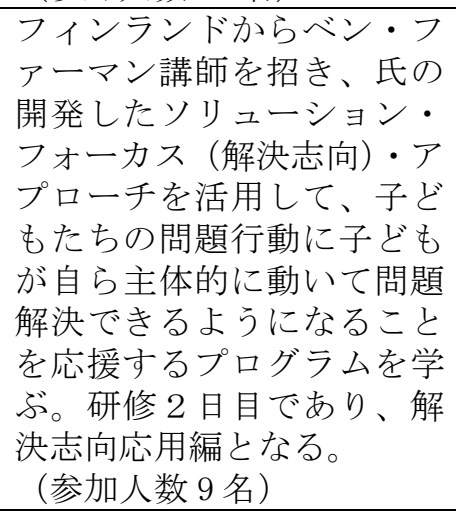 & $\begin{array}{l}\text { 家族支援 } \\
\text { 者 }\end{array}$ & 同上 \\
\hline $\begin{array}{l}2012 \text { 年 } 9 \\
\text { 月 } 1 \text { 日 }\end{array}$ & $\begin{array}{l}\text { 児童相談現場にお } \\
\text { ける「介入支 } \\
\text { 援」を巡って }\end{array}$ & $\begin{array}{l}\text { 大阪市立子育て } \\
\text { いろいろ相談セ } \\
\text { ンター }\end{array}$ & $\begin{array}{l}\text { 支援者の研修会。虐待相談 } \\
\text { の占める割合が年々増え、 } \\
\text { 児童相談所のあり方は大き } \\
\text { く変わっている。自ら相談 } \\
\text { に訪れる人のニーズに対応 } \\
\text { した支援だけでなく、子ど } \\
\text { も安全を守るためには、 } \\
\text { ニーズないところにも介 } \\
\text { 入する役割が大きくなって } \\
\text { きている。なおかつ、児童 } \\
\text { 相談所には介入するだけで } \\
\text { なく、親子分離した家族を } \\
\text { 再び統合してい支援の役 } \\
\text { 割も求められており、この }\end{array}$ & $\begin{array}{l}\text { 家族支援 } \\
\text { 者 }\end{array}$ & $\begin{array}{l}\text { 家族支 } \\
\text { 援の基 } \\
\text { 礎的理 } \\
\text { 解之し } \\
\text { て効果 }\end{array}$ \\
\hline
\end{tabular}




\begin{tabular}{|c|c|c|c|c|c|}
\hline & & & $\begin{array}{l}\text { 困難な状況を理解寸るため } \\
\text { に、改めて「介入」と支 } \\
\text { 援」について考える。現状 } \\
\text { を整理し、子どもたちの最 } \\
\text { 善の利益のためにどんなこ } \\
\text { とが必要なのか検討を行 } \\
\text { う。 } \\
\text { (参加人数 } 56 \text { 名) }\end{array}$ & & \\
\hline $\begin{array}{l}2012 \text { 年 } 9 \\
\text { 月 } 7 \text { 日 }\end{array}$ & $\begin{array}{l}\text { 研修会「長続きする } \\
\text { 家族支援のために } \\
\text { 一支て支援者応 } \\
\text { 援セミナー」 }\end{array}$ & $\begin{array}{l}\text { 青森県むつ市中 } \\
\text { 央公民館 }\end{array}$ & $\begin{array}{l}\text { 児童相談所の職員、地域の } \\
\text { 民生児童委員、学校の先生、 } \\
\text { 子育てN P O関係者を対象 } \\
\text { に研修会「長続きする家族 } \\
\text { 支援のために充て支产 } \\
\text { 者援セミナー」と題し講 } \\
\text { 演。 } \\
\text { (参加人数 } 80 \text { 名) }\end{array}$ & $\begin{array}{l}\text { 家族支援 } \\
\text { 者 }\end{array}$ & $\begin{array}{l}\text { 他府県 } \\
\text { の展 } \\
\text { 開支援 }\end{array}$ \\
\hline $\begin{array}{l}2012 \text { 年 } 9 \\
\text { 月 } 7 \text { 日 }\end{array}$ & $\begin{array}{l}\text { ワークショップ「お } \\
\text { 父さんのコミュニ } \\
\text { ケーション教室一 } \\
\text { パパ素敵！にしま } \\
\text { す」 }\end{array}$ & $\begin{array}{l}\text { 青森民県むつ市中 } \\
\text { 央公民館 }\end{array}$ & $\begin{array}{l}\text { 本プログラムを虐待予防と } \\
\text { して編成して一般向けに開 } \\
\text { 催 } \\
\text { (参加人数 } 18 \text { 名) }\end{array}$ & $\begin{array}{l}\text { 一般の方 } \\
\text { 向け }\end{array}$ & $\begin{array}{l}\text { 一般化 } \\
\text { にむけ } \\
\text { て始動 }\end{array}$ \\
\hline $\begin{array}{l}2012 \text { 年 } 9 \\
\text { 月 } 27 \text { 日 }\end{array}$ & $\begin{array}{l}\text { 第 } 1 \text { 回福祉社会フォ } \\
\text { ーラム } \\
\text { テーマ「子ども・家 } \\
\text { テーマ「族・国家をめぐる社 } \\
\text { 会臨床」 }\end{array}$ & 京都府立大学 & $\begin{array}{l}\text { 本プログラムを虐待予防と } \\
\text { して編成して開催 } \\
\text { (参加人数 } 60 \text { 名 })\end{array}$ & $\begin{array}{l}\text { 支援者並 } \\
\text { びに一般 } \\
\text { の向け }\end{array}$ & $\begin{array}{l}\text { 啓発普 } \\
\text { 及民しし } \\
\text { て評価 }\end{array}$ \\
\hline
\end{tabular}

(3) 新聞報道、TV放映、ラジオ報道、雑誌掲載等
(1)新聞報道
(2)TV 放映
(3)ラジオ報道
(4)雑誌掲載

なし。

\section{（4）論文発表（国内誌２３件、国際誌０件）}

2009 年度（後半期）

中村正「逸脱行動と社会臨床一加害に対応する対人援助学」、『対人援助学の可能性一「助ける 科学」の創造と展開』望月昭、中村正、サトウタツヤ、武藤崇編、127-166 頁、福村出版、2010 年 03 月

中村正「親密な関係性における葛藤と暴力一問題解決にむけた新しい臨床論」『家族社会学を学ぶ 人のために』井野真理子編著、世界思想社、2010 年 1 月

中村正「男性のためのグループワークーDV 加害男性、虐待親、性犯罪者たちとのセッションの 経験から」、『集団精神療法』、第 25 巻 1 号、2009 年 12 月

中村正「家族不安社会における親の欲望 : 親の問題として考える家族病理」、『家族療法研究』、 第 26 巻 3 号、206-213 頁、日本家族研究・家族療法学会、2009 年 12 月

中村正「社会の変化と臨床のかたち一家族の臨床社会学」、家族療法研究』、第 26 巻 3 号、230-235 頁、2009 年 12 月

\section{0 年度}

中村正「相互作用と暴力一微視的社会学の視点一」『世界人権問題研究センター紀要』16 号、 105-131 頁、世界人権問題研究所、2011 年 3 月

中村正「社会臨床の視界 (4) 社会の詩的言語としての臨床と表象」『対人援助学マガジン（デ ジタル)』第 4 号、日本対人援助学会、2011 年 3 月

中村正「社会臨床の視界（3）社会臨床という思考のレッスンーメビウスの輪のようにねじれて 
つながる関係性を理解する一」『対人援助学マガジン (デジタル)』第 3 号、日本対人援助学会、 2010 年 12 月

中村正「社会臨床の視界（2）「あいだ」への関心一加害者臨床一」『対人援助学マガジン（デジ タル)』第 2 号、日本対人援助学会、2010 年 10 月

中村正「加害者臨床のめざすことーD V ・虐待に焦点を当てた脱暴力への支援をとおして」『季 刊刑事弁護』第 64 号、2010 年 10 月

中村正「社会臨床の視界（1）歴史のなかの臨床課題」『対人援助学マガジン（デジタル）』第 1 号、日本対人援助学会、2010 年 7 月

中村正「親密な関係性における虐待・暴力と加害者臨床論一虐待的パーソナリティ論の検討を とおして」、『立命館産業社会論集』第 46 巻第 1 号、2010 年 6 月

\section{1 年度}

徳永祥子「〈海外視察報告〉英国の治療的養育と地域非行対策について一児童自立支援施設の将 来展望を添えて」、『非行問題』213 号、全国児童自立支援施設協議会、2012 年 3 月

久保樹里「目の前にいる子どものそだちを保障する地道な支援」、『そだちと臨床』第 10 号、明 石書店、2011 年 4 月

中村正監訳『虐待的パーソナリティ』（ドナルド・ダットン著）、2011 年 8 月、明石書店

中村正「社会臨床の視界（5）影をとらえる一感情について」、2011 年 6 月、『対人援助学又ガ ジン (デジタル)』第 1 巻 5 号、14-26、日本対人援助学会

中村正「社会臨床の視界 (6) 臨床の知の植民地化についてーどんな言葉と文脈で対人援助を考 えるか」、2011 年 9 月、『対人援助学マガジン (デジタル)』第 1 巻 6 号、14-25 頁、日本対人援 助学会

中村正「『加害者治療』の観点から一暴力加害者への臨床論のために」、2011 年 10 月、『法と心 理』第 11 巻 1 号、14-20 頁、法と心理学会

中村正「親密な関係性における男性の暴力への対応一加害者リハビリテーションの実践から」、 2011 年 10 月、『月刊地域保健』第 42 巻 10 号、42-46 頁

中村正「社会臨床の視界（7）－男親と父親の『あいだ』にある父性の涵養」、2012 年 1 月、『対 人援助学マガジン (デジタル)』第 7 号、14-26 頁、日本対人援助学会

中村正「社会臨床の視界（8）－家族をシステムとしてエコロジカルにみること」、2012 年 3 月、 『対人援助学マガジン (デジタル)』第 8 号、15-24 頁、日本対人援助学会

2012 年度（前半期）

中村正「社会臨床の視界（9）一ケア・リーバーCare Leaver たち一『忘れられたオーストラ リア人』への謝罪から考える一」、2012 年 6 月、『対人援助学マガジン (デジタル)』、第 9 号、 14-25 頁、日本対人援助学会

中村正「社会臨床の視界（１０）－ソーシャル・ナラティブと社会臨床一変わりにくい日常と いう物語を書き換えることの重要性と社会の物語構造に着目することの意義について一」、『対 人援助学マガジン (デジタル)』第 10 号、日本対人援助学会、15-26 頁、2012 年 9 月

\section{（5）WEB サイトによる情報公開}

(1)対人援助学会ホームページ

「対人援助学デジタルマガジン」

http://www. humanservices. jp/magazine/index. htm1

にて、本プログラムの成果を含む臨床家族理論などについて「社会臨床の視界」と題して 連載中（現在、第 10 号までフリーダウンロード可能）

(2)人間科学研究所ホームページ

http://www. ritsumeihuman. com/members $/ \mathrm{read} / \mathrm{id} / 50$

にて、実装責任者中村が所属する所属人間科学研究所における「臨床社会学の研究」につ いてのプロジェクト紹介並びに研究業績を公開している。

（3)男親塾の情報・支援者支援研修の情報を載せた「男親塾」H P を作成した。 http://otokooya. com/schedule

(4)戦略的研究基盤形成支援事業ホームページ

http://www. ritsumeihuman. com/cpsic/member2. htm1\#top2 
にて、人間科学研究所が採択を受けている文部科学省戦略的研究基盤形成支援事業の「D $\mathrm{V}$ 加害者に対するアプローチ」課題について紹介並びに研究成果を公開している。

\section{（6）口頭発表（国際学会発表及び主要な国内学会発表）}
(1)招待講演
（国内会議
件、国際会議
件)
(2)口頭講演
(3)ポスター発表
（国内会議
件、国際会議
件、国際会議
（国内会議

なお特記事項として、この口頭講演には代表者が所属する学会での発表以外に、このプロジ エクト期間中に、このプロジェクトのテーマにかかわり、日本家族看護学会、日本家族研究・ 家族療法学会、法と心理学会、日本心身医療学会の各学会から招待講演を依頼されたものが含 まれている。関心の広がりを実感している。

\section{(7) 特許出願}

(1)国内出願

1. “発明の名称、発明者、出願人、出願日、出願番号”

2 .

・・・

(2)海外出願 件)

1. “発明の名称、発明者、出願人、出願日、出願番号”

2 .

•.

\section{（8）その他特記事項}

\section{VI 結び}

\section{実装の目標に照らした達成度}

当初は大阪市児童相談所との連携でスタートしたプログラムが、大阪府内五力所と政令市である 大阪府堺市児童相談所へと拡大して実装できた。これで大阪府内全域に広がったこととなる。 さらに近畿の児童相談所の幹部研修会も開催し、近隣府県に広げる手がかりを得た。また、家 庭内暴力対策としては高齢者虐待へも応用する手がかりを大阪市（ケアマネジャーの組織）で 得ることができ、当初は計画していなかった実装先となりつつある。どの国でも地域でも直面 している社会問題としての虐待に対応する総合的なケースワークの仕組みとしての本実装プロ グラムは家族再統合後にあっても家族支援が可能なフレームなので効果的である。なお、大阪 市における虐待による介入で子どもの一時保護の後、児童養護施設に入所したケースは平成 22 年度で 205 人となっており、現在、本プログラムに登録している家族が大阪市分で 22 家族とな っている。

\section{得られた成果の意義などの自己評価}

虐待する家族への家族再統合計画の組み立て、グループワークや個人と夫婦へのカウン 
セリング、合同家族面接というファミリーカウンセリングの実施、児童相談所としてのケ 一スワーク、家族にかかわる多職種連携会議の実施、家族再統合後の家族支援という一連 の流れをつくり、家族システムの変容を支えることがこのプログラムの内容である。そし てそれらを支える臨床家族理論を構築してきた。大阪市と大阪府に実装できたことは成果 であるし、このフレームはどの地域でも応用可能である。この実装をもとにした援助理論 モデルと一連の仕組みによる実践を研修内容として編み上げ、それを人材育成へと精緻化 することにより児童相談所での家族支援として標準的に実装可能なものとしていくこと ができる。虐待する親へのグループワークをはじめとした総合的な支援をもとにした家族 システへの介入から再統合後の支援までを一貫した仕組みのもとに構築できているのは 大阪がはじめてである。もちろん虐待家族の動向からすればこの実装プログラムにのせる ことができた家族は総数のうちの10\%程度となっているので、さらにこの比率をあげるこ とが課題である。

\section{今後の自立的継続可能性}

すでに大阪府内の各児童相談所では、本プログラムにもとづく虐待家族対念について今 年度後半期の計画もたてており、心理士と福祉司向けの研修会も予定されているなど、い ったん開始した家族再統合プランをもとに作動している家族は合計で府と市の分あわせ て35家族（一家族は京都市に転出したがここに継続参加しているのでこの数に含んでいる） をかぞえており、さらに家庭裁判所の措置の判断が 2 年にわたることともかかわり、実 装プログラム継続は前提となっている。さらに、近隣府県への拡大の可能性、人材育成面 での継続研修制度の確立、家庭内暴力全体への応用の三点については発展させることが可 能となっている。なお、本実装プログラムに参加している家族を対象にしてより精緻な臨 床家族理論を構築することを研究課題として申請した科学研究費補助金／基盤研究（C） 一般 H24-H26（日本学術振興会）「虐待が生成する家族の相互作用と関係性の特性につ いての臨床社会学的研究」（中村正代表、計481万円）が採択されたことも今後の継続性 を保証するものとなっている。さらに、立命館大学の地域連携のための研究拠点形成事業 である「立命館グローバル・イノベーション研究機構」の公募プロジェクトとして「法心 理・司法臨床センター」プロジェクト (Center for Forensic Clinical Psycholo-gy、 中村は共同リーダーのひとり、申請予算規模は 1 億5000万円）が採択された。本プログラ ムはそのなかの一部として位置づけているのでここでの成果の継承を組み込んでいる。こ れは平成 24 年 10 月 1 日から 3.5 年間のプロジェクト実施となっており、継続と発展の条件は 整っている。

プロジェクト運営についてのまとめ

実装先との連携がスムーズであり、組織体制としては十分であった。実装先の拡大にともな 
うケースワーク進行に際しての連携空口の緻密さが求められる点があり、事業拡大にともなう 課題が浮上した。この点については大阪府下担当者を一元化することにより現在は首尾よくす すんでいる。こうしたヒューマン・サービスのプログラムの実装に関しては連携先の担当の心 理士と福祉司との緊密な連携のためのマネジメントがかぎとなる。そのためにも現場のニーズ を汲取り、家族再統合の援助技術に長けた職員の養成は急務となっている。運営としてはこ のニーズを研修テーマとして取り上げ、実践一研修一力量向上一事例検討会による相互研鑽と いう好循環ループができつつある。この意味では効果的な運営となった。また、大学の実務空 ロがリエゾン活動に長けていたこともあり運営全般はスムーズであった。 
補足資料：事後評価面談資料

平成 21 年度課題 研究開発成果実装支援プログラム

家庭内児童虐待防止に向けたヒューマンサービスの社会実装

中村 正 (立命館大学)、久保樹里（大阪市こども相談センター）

2012 年 11 月 13 日 @ JST 東京本部別館

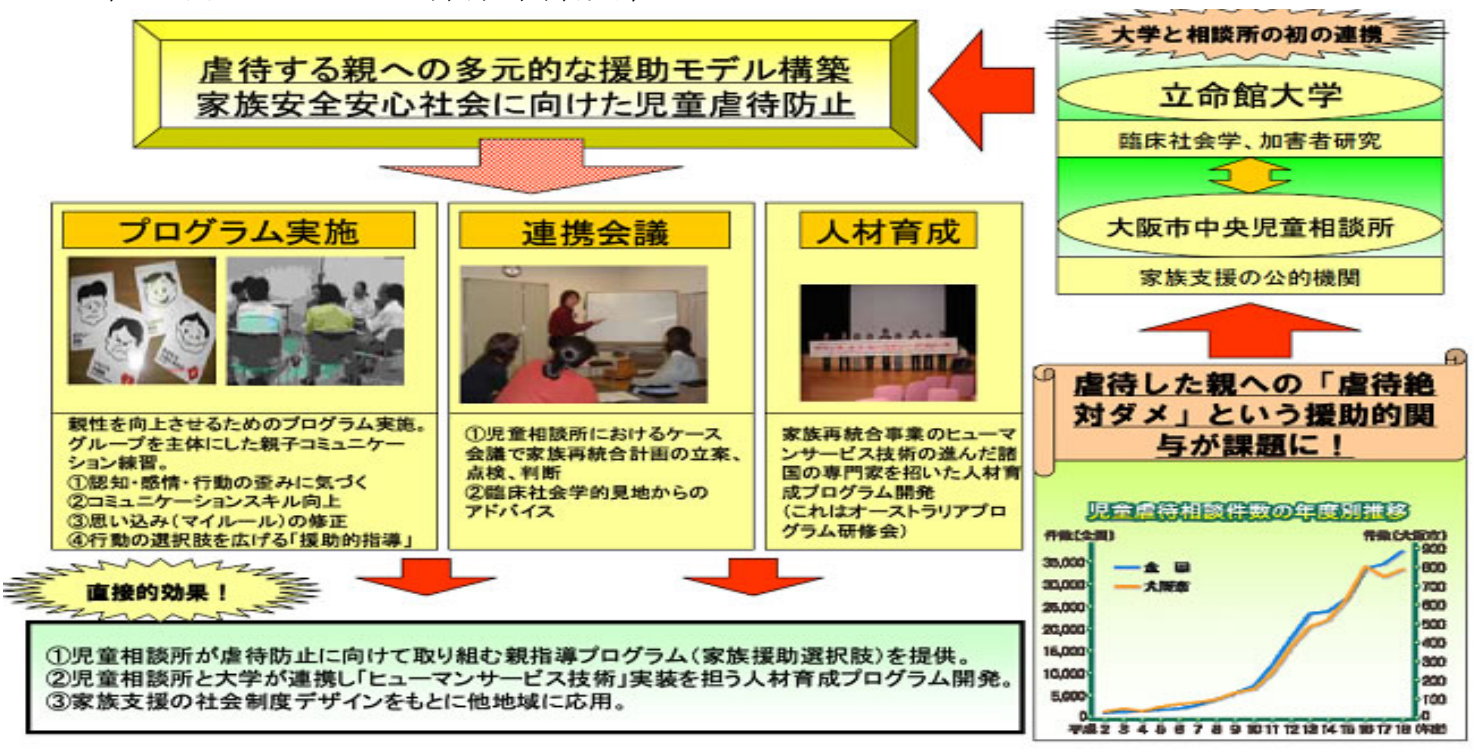

目的:

・ 家族安全安心をめざすヒューマンサービス技術をもちいた虐待防止の家族援助をおこな う。大阪市こども相談センターと連携して、家族再統合事業の社会実装をおこなう。

- 具体的な活動内容の特徵として、第一に、虐待防止にむけて取り組む対人家族援助のため の具体的な方策を提供する。第二に、児童相談所と大学が連携して人材育成をおこなう。 第三に、ヒューマンサービスとしては汎用性が高く、各地における応用が期待できる。

経過：

- 大阪市こども相談センターと連携して、虐待する家族への非暴力・脱暴力への行動変容へ の多元的な援助モデルを構築し、家族援助のためのヒューマンサービス技術として開発し たプログラムを家族再統合事業として、児童相談所の援助の選択肢の一つとして実装する ことが最終目標である。・・览童相談所と連携した親指導プログラムを家族再統合事業 として完成させる。将来は、他地域への応用をめざす家族安全安心をめざすヒューマンサ 一ビス技術をもちいた虐待防止の家族援助として体系化する予定である。具体的には、大 阪市こども相談センターと連携して、必要な連携会議をもち、人材育成のための研修ワー クショップを開催し、児童虐待防止法において喫緊の課題となっている親指導の課題を解 決する。

・ 実装責任者は、これまで、家族再統合援助の実践モデル・技法と行動変容にむけた援助理 論の開発を目的とした科研費等による研究を行ってきた。

- 第 1 は臨床実践モデルの構築、第 2 は連携の仕組みの開発、第 3 は加害者臨床理論の構築 である。その際に、諸外国で取り組まれている虐待親アプローチの理論的な援助モデルや 援助仮説を検討した。それらを仮説形成に役立て、家族制度や家族意識が異なる日本社会 に適合するようなアプローチを追求するために、実装責任者が試行的に開発し、実践して いるグループワークと並行面談を実施した。これらをまとめて、「家族再統合への修復モ デル」として構築しつつある。実践グループを「家族ケアユニット」と称して児童相談所 の外部に位置づけて実施している。最終的には、日本の虐待・D Vにそくした援助理論モ デルとグループワークなどの内容を構築することを目的とした研究を重ねてきた経緯が ある。本プログラムはこうした成果を安定的なプログラムとして児童相談所に実装する。

効果 :

支援期間終了後の計画において継承すべきは、第 1 は虐待ゼロ制度モデルの構築、第 2 は 連携の仕組みの開発、第 3 は臨床理論の構築である。この実践をするグループを「家族ケ アユニット」と称して児童相談所の外部に位置づけて実施するというフレームはどの地域 
でも応用可能である。最終的には、日本の虐待・D V そそくした援助理論モデルとグルー プワークなどの内容を構築することを目的としているので、児童相談所に標準実装する可 能性を模索し、より公共性の高い事業となることが期待される。

その後の政策動向 :

社会的養護強化（厚生労働省）－「親子関係再構築支援」について一：

(1)社会的養護の施設においては、虐待を受けた児童の早期の家庭復帰や、家庭復帰後の虐 待の再発防止のため、また、家庭復帰はしない場合でも親子関係の回復のため、さらに親 子分離に至らない段階での親支援のため、虐待防止の保護者援助プログラムを含め、親子 関係の再構築支援が重要である。子どもにとって、その生い立ちや親との関係について、 自分の心の中で整理をつけられるよう、親子関係の再構築について、子どもに対する支援 も必要である。

(2)親子関係の再構築等の家庭環境の調整は、措置の決定・解除を行う児童相談所の役割で あるとともに、児童福祉施設最低基準に定められた施設の役割でもあり、施設は、児童相 談所と連携しながら、社会的養護の地域支援の拠点として、その取組を推進する。また、 児童家庭支援センターも、施設と地域をつなぐ拠点として、親子関係の再構築支援におけ る役割の充実が期待されている。

(3)平成 23 年 7 月の「社会的養護の課題と将来像」一地域支援の役割を高めていく社会的 養護の施設の方向性として、施設による親子関係の再構築支援の充実を掲げ、効果的な手 法の開発・普及、支援者のスキルの向上、体制整備の推進、児童相談所との連携などを図 っていくこととした。

実装プログラム予備的考察(1)「他罰性」がかぎとなること

○脱暴力プログラム参加者調査

2010 年 4 月から 9 月まで隔週 12 回にわたって行われた、筆者らが実施する男性向けのグ ループワーク（以下、プログラム）1クールにおいて、参加者へのアンケート調査を実施

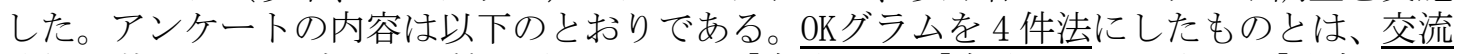

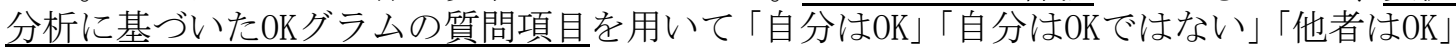
「他者はOKではない」の 4 つの態度の変化（プログラム参加の前後比較）を見るものであ る。各態度 10 項目ずつ合計 40 項目の質問紙である。「当てはまらない」「少しだけ当ては まる」「まあまあ当てはまる」「よく当てはまる」の 4 件法として・・数量化して検定をお こなった。

実装プログラム予備的考察(2)アンケート調査と文章完成法調査

- 10 種類の尺度 $=「$ 自己肯定感」「攻撃性」「優越感」「協調性」「他者肯定感」「共感性」「動 機づけ」「自己一致」「ジェンダー意識」「完璧主義」の 10 種類の尺度について、4 件法で 回答してもらい、それぞれに 1 点〜4 点を与えて変化をみた。

・ 上記にかかわり、「私は・・・。」という文章完成法による語彙と感情についての変化をみ た。

実装プログラム予備的考察(3)結果 1

攻撃性に関して尋ねた「カッとなることを抑えるのが難しいということがある」という質 問項目に対する男性（6名：1 名はこの質問項目に 1 度しか回答なかったため除外）の回 答に、プログラム参加前後で統計的有意差が見られた。参加開始直後は平均值 3.5(SD0.84) だったのが、参加後（回答のあった最後の回）の平均点は 2.5（SD1.05）となった。 $\mathrm{t}$ 検 定（両側）の結果 $\mathrm{p}<.05 、 5 \%$ 水準で有意差があることが示された。つまり、男性が「カ ッとなることを抑えるのが難しいということがある」と感じる度合いが、プログラム参加 後に下がっていることが統計的に示された。

実装プログラム予備的考察(4)結果 2

ジェンダー意識を尋ねた「男性と女性は、本質的に違う」という質問項目に対する男性 (7 名）の回答に、プログラム参加前後で統計的有意差が見られた。参加開始直後は全員が「よ く当てはまる」と答え、平均值 4.0 だったのが、参加後（回答のあった最後の回）の平均 点は2.71（SD1.11）となった。 $\mathrm{t}$ 検定（両側）の結果 $\mathrm{p}<.05 、 5 \%$ 水準で有意差があるこ とが示された。つまり、男性が「男性と女性は、本質的に違う」と感じる度合いが、プロ グラム参加後に下がっていることが明らかになった。

実装プログラム予備的考察(5) 結果 3

(1)「自分はOKではない」 
参加前の 7 名の平均点は 22.0（SD4.55）、参加後の平均点は 19.0（SD5. 29）であり、 $\mathrm{t}$ 検 定（両側）の結果 $\mathrm{p}<.10$ であった。 $5 \%$ 水準で有意とは言えないものの、有意差のある傾 向が示された。7名のプログラム参加者は、参加後に「自分は $0 \mathrm{~K}$ ではない」のポイントが 下がる傾向が示唆されたことになる。

(2)「他者はOKではない」

参加前の 7 名の平均点は 21.1 （SD5. 58）、参加後の平均点は 17.3（SD7.34）であり、 $\mathrm{t}$ 検 定（両側） $\mathrm{p}<.05$ で、 $5 \%$ 水準で有意差があることが示された。 7 名のプログラム参加者 は、参加後に「他者は $\mathrm{OK}$ ではない」のポイントが下がったことが統計的に示された。

虐待のある家族のやり直し支援 (1)

それは何であるのか「家族再統合事業 (览童虐待防止法)」しかし、

「元のさやには収まらない家族」 $\rightarrow$ 「新しいさやを作ること」

虐待のある家族のやり直し支援(2)何が目的なのか

進め方 (介入と支援と)

(1)パターナリズムの利活用

(2)子どもの意思確認の方法

(3)家族システムのアセスメント

(4)親支援プログラム

(5)全体のケースマネジメント

虐待のある家族のやり直し支援(3)゙のようにすすめるのか

(1)ジェノグラムの活用（潜在力、ストレングス、拡大家族、ソーシャルアトム）

(2)ファミリーカンファレンシング方式

(3)プロセス管理とケースマネジメント

(4)ファミリーグループ・カンファレンス

(5)家族再統合計画、選択肢と社会資源の準備

(6)多職種連携会議、家族再統合後のケア・・・

虐待のある家族のやり直し支援(4)虐待のある家族の特性理解

・虐待類型ーアビューズ型とネグレクト型の違い

・クライアント特性ージャスティスクライアント

・男性問題というマク口変数一父親と母親の差異化

・ジェノグラム特性の把握一三世代

・働きかける対象の見極めーシステムとしての家族

背景(1)児童相談所における虐待相談件数の推移 平成11～23年

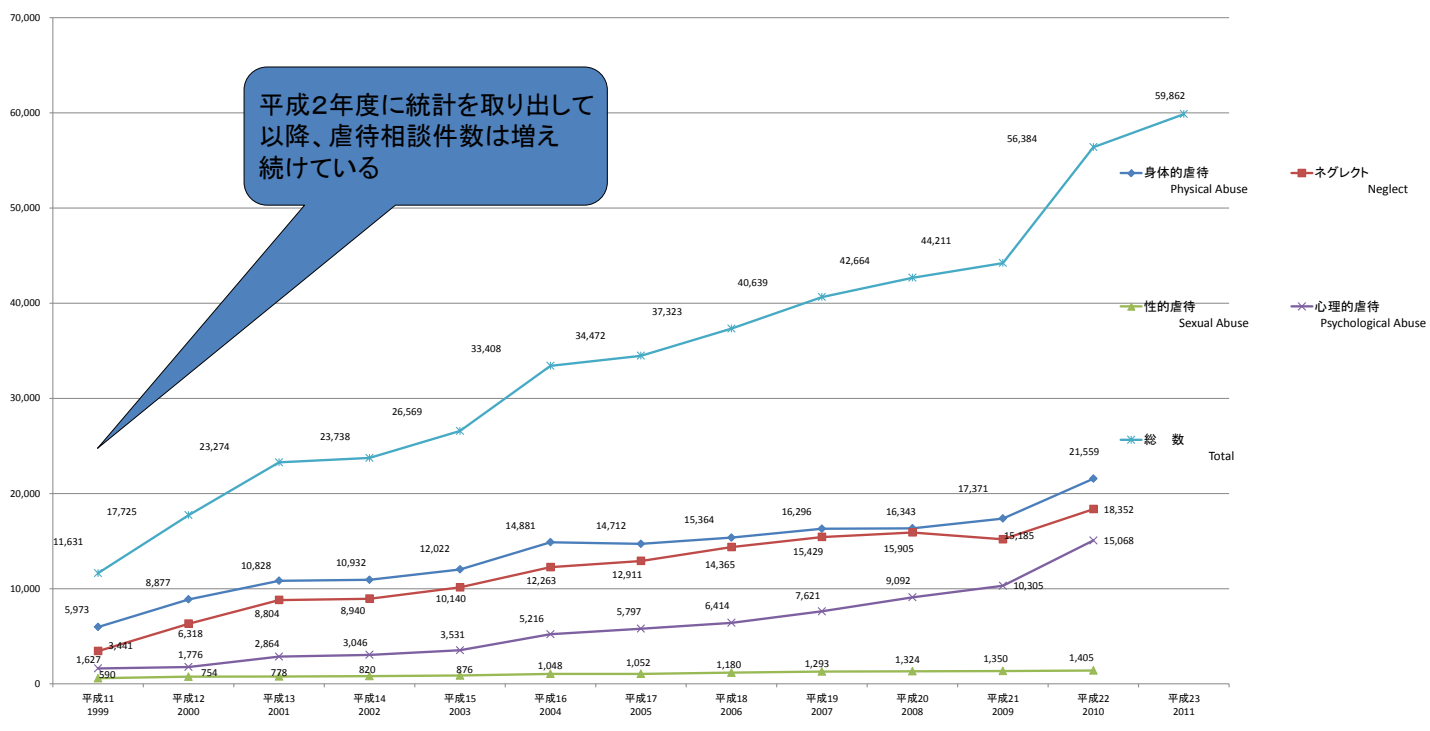


背景(2)児童虐待の種別

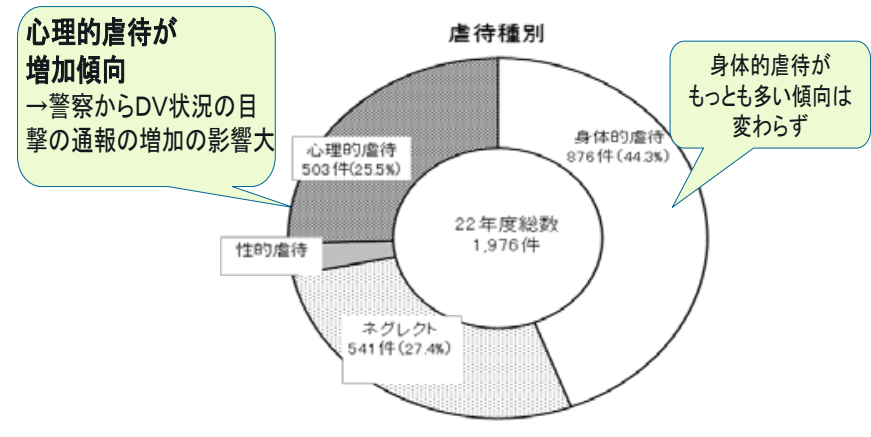

大阪市の状況

\section{背景(3)児童虐待の加害者}

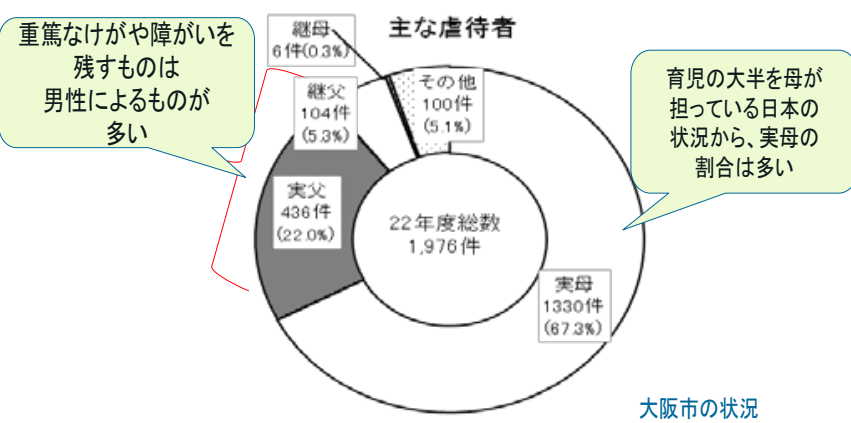

背景(4)虐待で保護する子どもの増加

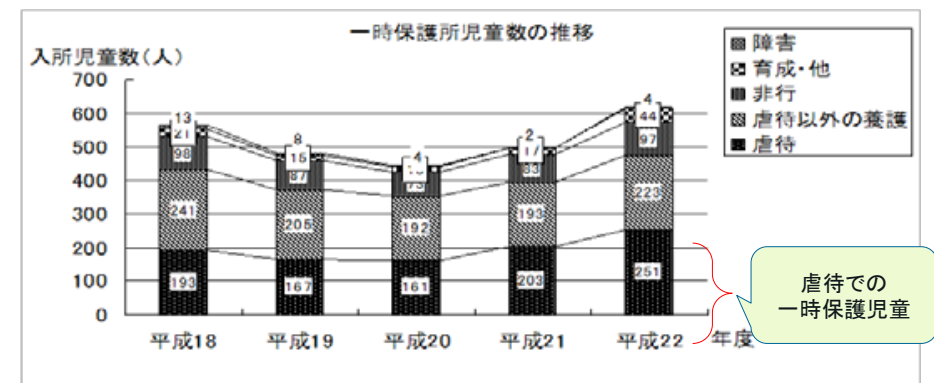

背景(5)平成18年度から家族再統合のメニュ一を充実させる 大阪市児童虐待からの家族回復支援事業

\begin{tabular}{|c|c|c|c|c|c|c|}
\hline \multicolumn{2}{|r|}{ 事業名 } & 内容 & 人数 & 開催日時 & \multirow{2}{*}{$\begin{array}{c}\text { 場所 } \\
\text { こども相談センター }\end{array}$} & \multirow{2}{*}{$\begin{array}{c}\text { 備考 } \\
\text { 空き状況は要確認 }\end{array}$} \\
\hline \multirow{4}{*}{ 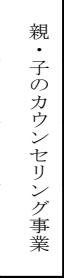 } & \multirow[t]{2}{*}{ 個人カウンセリング } & 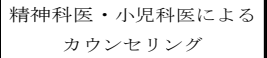 & 個別 & 月 $1 \sim 2$ 回 1 時間 & & \\
\hline & & $\begin{array}{l}\text { 心理士による } \\
\text { カウンセリング }\end{array}$ & 個別 & 月 $1 \sim 2$ 回 1 時間 & こども相談センター & 空き状況は要確認 \\
\hline & $\begin{array}{c}\begin{array}{c}\text { グループカウンセリング } \\
\text { (スペース A })\end{array} \\
\end{array}$ & \begin{tabular}{|c|} 
コラージュ (芸術療法) を取り \\
入れた語り合いのグループ
\end{tabular} & 6 人まで & \begin{tabular}{|r|r|} 
第 2.4 火曜 & 午 \\
前 1 O 時半から 5 午後 12 時
\end{tabular} & こども相談センター & 空き状況は要確認 \\
\hline & $\begin{array}{c}\text { ファミリーグループ・ } \\
\text { カンファレンス }\end{array}$ & 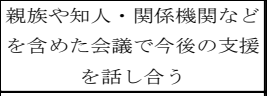 & 10 人まで & 必要な場合に開催 & こども相談センターなど & \begin{tabular}{|c|} 
外部コーディネーターが \\
進行役をつとめる \\
平成2 3 年度からの新規事業 \\
\end{tabular} \\
\hline & $\begin{array}{l}\text { TREE ペアレンツ・ } \\
\text { プログラム }\end{array}$ & \begin{tabular}{|c|} 
親の自尊心を高め、虐待をやめ \\
るための親の自己回復ブログラ \\
ム、心身耐方に偅きかける \\
\end{tabular} & 約 10 人 & $\begin{array}{l}8 \text { 月末から } 12 \text { 月ながばまで } \\
\text { 火曜午後 } 1 \text { 時半から } 4 \text { 時、3 } \\
\text { 月に } 1 \text { 度、振り返り (15 回) }\end{array}$ & $\begin{array}{c}\text { 社会福祉研修・情報 } \\
\text { センター }\end{array}$ & $\begin{array}{c}\text { 委託公募事業・保育あり } \\
\text { (保育は西成子育て支援せ } \\
\text { ンター) }\end{array}$ \\
\hline チャ & $\begin{array}{l}\text { 親子交流プログラム } \\
\text { イルドリソースセンター } \\
\text { プログラム } \\
\end{array}$ & \begin{tabular}{|c|} 
親子の交流場面を活用して、親 \\
子のかかわりを改善する \\
プログラム \\
\end{tabular} & \begin{tabular}{|c|}
2 組の親子 \\
個別実施
\end{tabular} & $\begin{array}{c}7 \text { 月末から赛施 } \\
\text { 隔週 約 } 2 \text { 時間 } \\
12 \text { 回のプログラム } \\
\end{array}$ & こども相談センター & $\begin{array}{c}\text { 委託公募事業 } \\
\text { 平成 } 23 \text { 年度か5の } \\
\text { 新規事業 } \\
\end{array}$ \\
\hline & $\begin{array}{c}\text { コモンセンス・ペアレン } \\
\text { ティング } \\
\text { トター・ペアレンティング }\end{array}$ & \begin{tabular}{|c|} 
虐待でない適切なしつけの \\
方法を学ぶ親教育
\end{tabular} & $\begin{array}{c}\text { 個別（複数 } \\
\text { も可能） }\end{array}$ & $\begin{array}{c}\text { 約 } 6 \text { 回 } \\
1 \text { 回は約 } 2 \text { 時間 } \\
\text { (不定期) }\end{array}$ & \begin{tabular}{|} 
状沉に合わせて、こども相 \\
談センターや区役所など
\end{tabular} & $\begin{array}{c}\text { 研修を受けた職員が実 } \\
\text { 施 }\end{array}$ \\
\hline
\end{tabular}




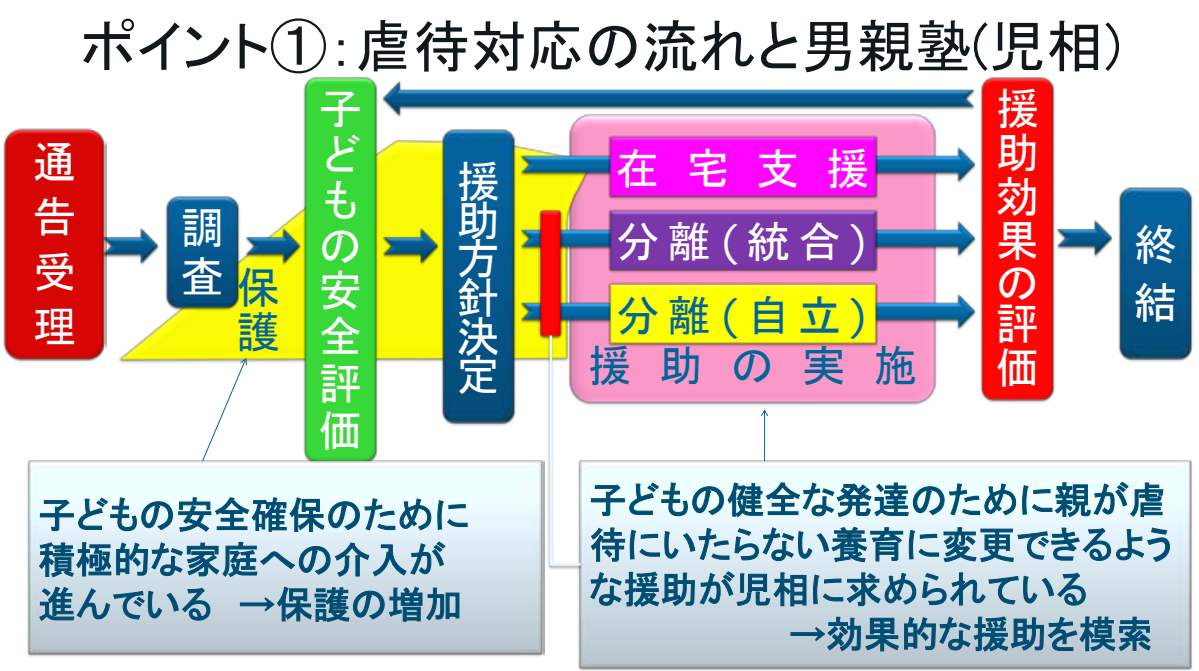

ポイント(2)一時保護所の退所状況（処理内容と保護期間）

退所実児童数は 611 人（虐待 252 人）。

そのうち、虐待の退所内訳

帰宅 128 人 $(50.8 \%)$
児童福祉施設入所 $\underline{96}$ 人 $(38.1 \%)$
里親委託 6 人 $(2.4 \%)$
その他 22 人 $(8.7 \%)$

ポイント(3)介入した家庭の保護者

「介入は支援のきっかけ」と言われるが・・・

*じんな姿勢や方法であっても家庭に介入された保護者はショック

怒り・悲嘆・否認・対立・攻撃・拒否が生成する

・これは虐待ではなく、しつけです。

・虐待ではありません。事故です。

・ロで言っても聞かないから体にわからせただけ。

・自分はもっとたたかれた。だからちゃんとした大人になれた。

・プライバシーの侵害、親は自分。

・勝手なことをするな。

・児童相談所はいつ子どもをとっていくかわからない。信用できない。

児相:介入と支援一相反する役割の難

しさ。特に男性へのかかわりの難しさ

外部機関との連携導入

家族システムと男性性を理解した支援とは

立命館大学人間科学研究所との

共同研究－男親塾の実践 


\section{実装プログラム(1)男親塾 参加状況}

\begin{tabular}{|c|c|c|}
\hline & 参加実人員 & 参加延へ人数 \\
\hline 2010 年度 & 18 人 & 111 人 \\
\hline 2011 年度 & 19 人 & 115 人 \\
\hline $\begin{array}{c}\text { 2012年度 } \\
\text { (9月末現在) }\end{array}$ & 20 人 & 83 人 \\
\hline
\end{tabular}

*グループは月2回 土曜午後に実施

*定期的に児相とのミ一ティングを開催

*必要に応じて、家族と男親塾スタッフ、児相の合同ミーティングも開催する

男親塾プログラム(2)親密な関係性と暴力

・認知の問題(コアとなっている信念、認知の枠、スキーマ)

・感情の生成(mind activation)

・強いる行動

・動機の語彙（中和化・被害者化の諸相含む）

・脱暴力八の変容

男親塾プログラム (4) 強いる行動の理解促進－ＡＢＣＤＥモデル

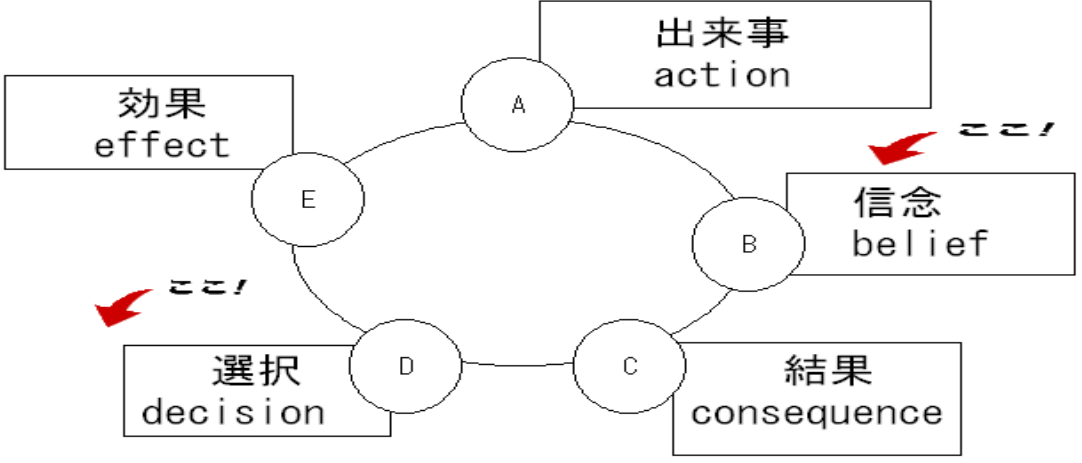

男親塾プログラム(5)暴力加害の動的リスク

自信過剩／良心の呵責の不足／罪の意識の不足

感性の不足／感情の乏しさ／他者に対する操作性／

親密な人間関係の不足／こんな出来事たいしたことな／

これは理由があってのことだ/相手のみくだし

出来事の否認／相手のせいにする／深く考えない／

援助を求めない／誰かに相談しない

男親塾プログラム（6) 加害や虐待の動的リスクとなる感情

- 怒り 苦痛優越感 悲しみ

- 恐れ 罪悪感孤独嫌悪

- 憂うつ失望傷つき安

- 恥喜び脄妬絶感

- 幸福感 欲求不満 好奇心

- 驚き満足感

— 被害意識 
男親塾プログラム(7)行動化としての暴力

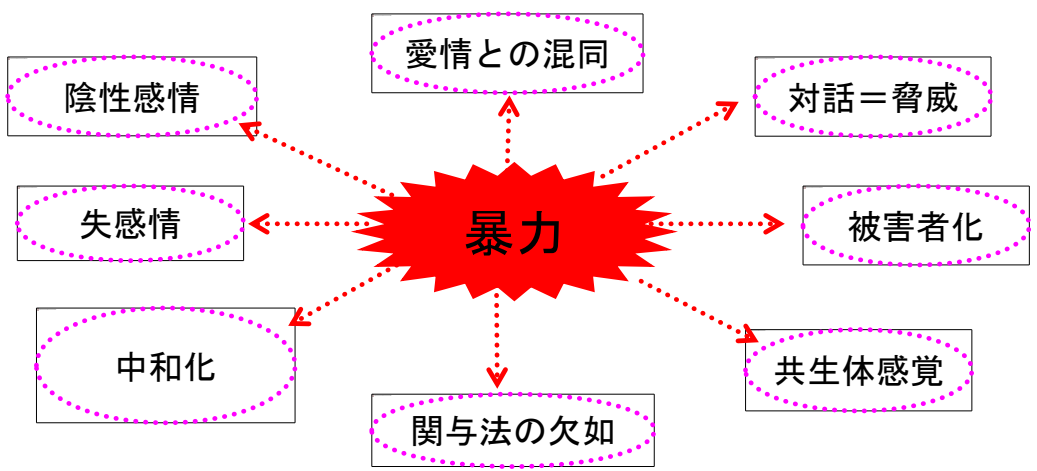

男親塾プログラム 8)コーピング行動とサイン
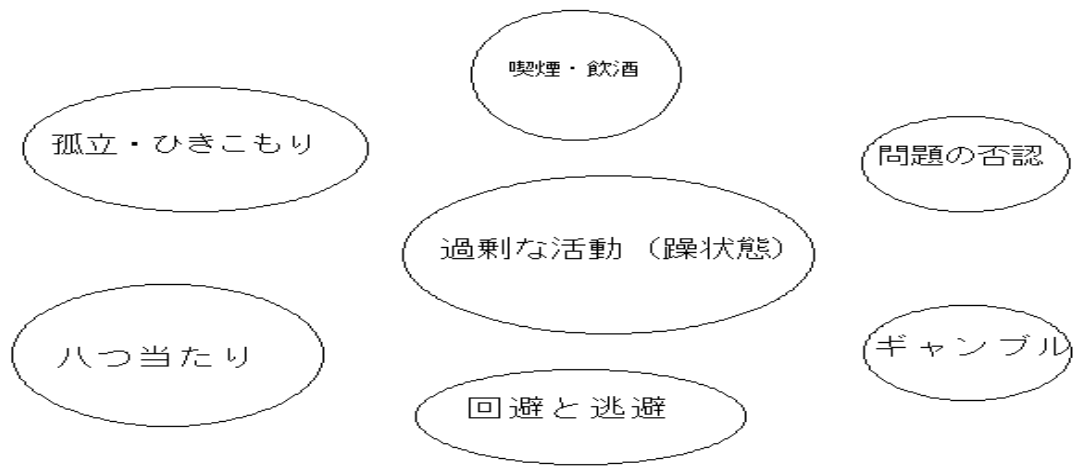

男親塾プログラム99別のコーピングヘ

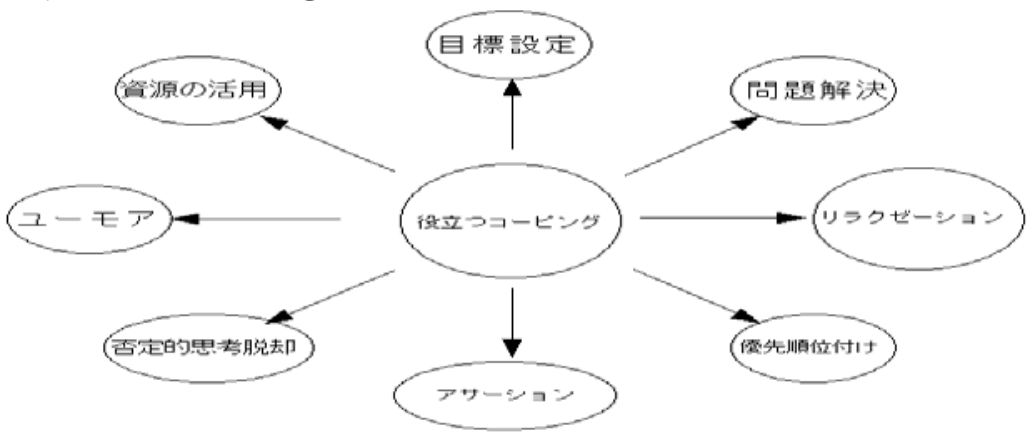

暴包生成の過程

男性性と親密さ

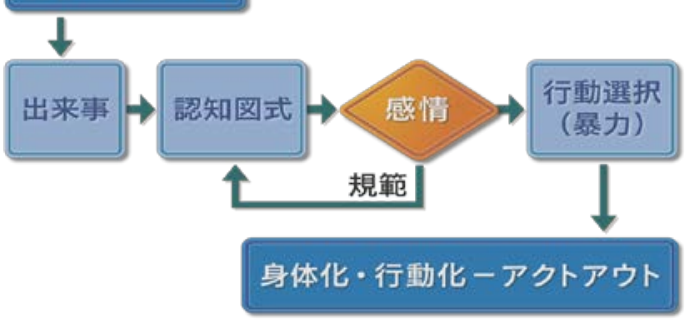

男親塾プログラム10問題解決的思考 


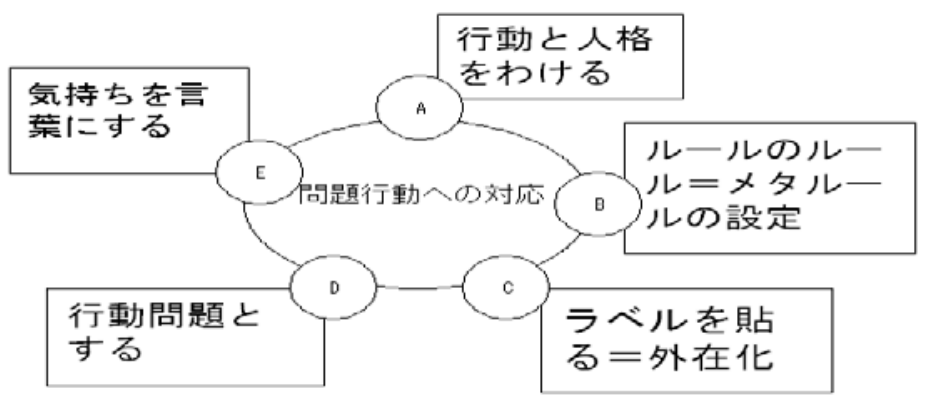

男親塾プログラム11)認知行動的な介入

- 認知行動療法のアプローチ

出来事一認知一感情一行動

認知の歪み、選択した行為、行動変容

脱学習の構造化

・グループワークの手法

加害者臨床の過程、グループワークであること

男親塾プログラム12父親たちの反応性の重視

・当事者のコミュニケーションモードがある

- 疎外感、否定された感＝愛着問題をかかえる

- 否認、正当化、中和化

- 防衛、抵抗、駆け引き、

・自分は被害者でもある

- 逃走と闘争

- 動機形成にむけて

- One size fits All という批判

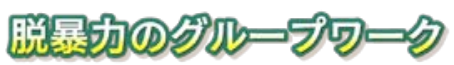

(1) 感情に気づく

(2) 身体を感じる

(3) 感情を伝える + 感情を聴く

(4) かかわりを感じる + 自己に気づく

(5) 男性同士の信頼を築く

(6) 非暴力への行動変容

男親塾プログラム(13)コミュニケーション訓練

(1)レポート・トークとラポート・トーク

(2)主語は誰か（一人称と三人称）

(3)私メッセージとあなたメッセージ

(4)マイルールからの脱出

(5)ファイティングモードの悪循環

(6)怒りマネジメント訓練（タイムアウト法など）

(7)ソーシャルスキルトレーニング

(8)アサーティブトレーニング

男親塾プログラ12男親塾に参加するのはどういう父か 
(1)介入後の男性への支援のメニューの一つに位置付けられ紹介されている。

例： 認知のゆがみの修正が必要と考える父

自信がなく、他の父の話が聞きたいという父

(2)たいていは、不本意ながらの参加＼cjkstart参加につなげるまでが非常に難しい

*児相は父の参加への動機付けを行う

例： 根気強い説得、裁判所の決定の機会を利用する

児相への抵抗のある人には「外部機関が実施」と説明する

支援の流れを図式化して説明する（視覚化）

母には家族回復支援事業のプログラムに参加を勧める など

(3)参加後、児相はソーシャルワーク的にかかわりを続ける

\section{参加者の一例 : Sさん}

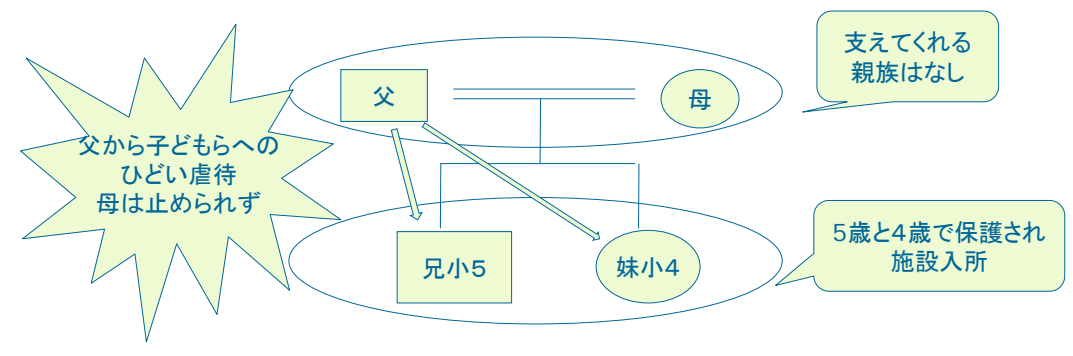

(1)子ども 2 人は幼児の時に父からの身体的・心理的虐待で職権保護 $\rightarrow$ 以降、児相との厳しい対立 関係

(2)子どもらは施設に入所、父への恐怖感消えず

(3)父母は個人カウンセリングに通いだすが児相との関係は膠着

(4)母がマイツリー・ペアレンツ・プログラムに通い出し、父には男親塾を紹介。そこから父が急 速に変化し、自分を振り返る。男親塾で自分の経験を語るようになる

(5)その後、父母の個人カウンセリングと夫婦面接も実施、児相からは支援計画を図式にして提示 ↔子どもらに父母の状況を伝える作業 手紙、写真、ボイスレター、ビデオレターの交換。子ど ものペースに合わせた地道な作業

(6)約 5 年ぶりの面会一抵抗なく父母に会える「父が変わった!」と子どもたち

(7)頻回なファミリーグループ・カンファレンスの実施

8外出、外泊を経て引き取りへ

996 年ぶりの同居、とまどい、苦悩を相談する父男親塾が引き取り後も支えになる

援助者支援「対人援助技術」の開発と訓練(1)エコマップ

「社会関係地図」「生態地図」。当該の家族の状況とその家族を取り巻くさまざまな社会環境や 人間関係について、関係性やプラスや、マイナスに作用する断面について、力動線の種類や矢印 の方向などで表す。

援助者支援「対人援助技術」の開発と訓練(2)ジェノグラムとエコマップ

当該家族の関係図を示すものをジェノグラムといい、それを用いた支援をおこなう。

援助者支援「対人援助技術」の開発と訓練(3)家族造形法 

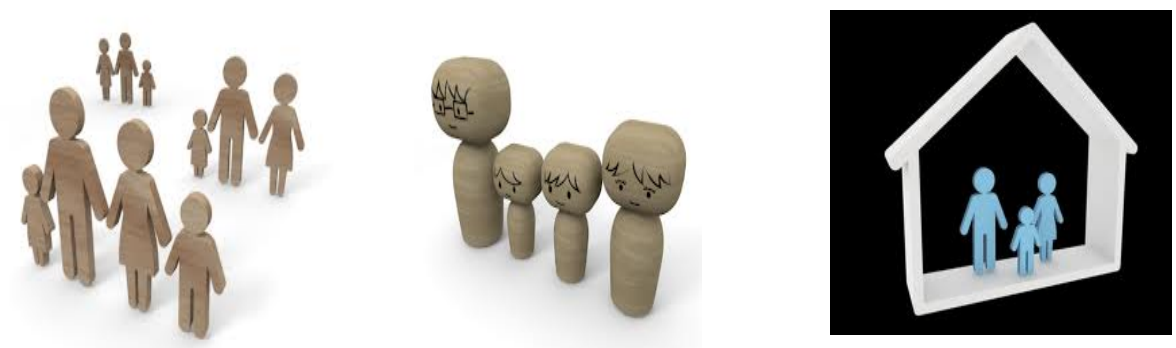

援助者支援「対人援助技術」の開発と訓練(4)ソリューションフォーカスト法（フィンラ ンド精神科医ベン・ファーマン氏）
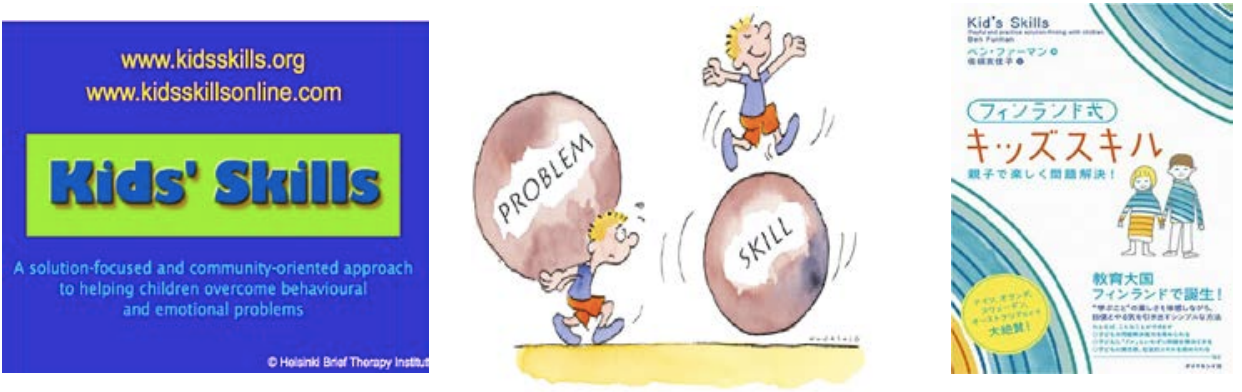

実装の結果(1)

家族再統合にむかった家族数

\section{2 家族}

・社会的養護とともに家族を営むことを選択する家族

・再統合の後も実装プログラムにのる家族

*子どもの最善の利益と子育ての仕方の継続練習と家族システムの安定

実装の結果(2)三つの広がり

○地域の拡大 大阪府内一円人

青森県むつ児相、滋賀県中央、京都市児相など地域レベルでの要請と研修

○対象の拡大 高齢者虐待と配偶者間暴力、ひきこもり家族への支援も

○領域の拡大 ヒューマンサービスとしての領域の拡大

実装の結果(3)

- 臨床の知による「融合と連携」の深化

- 社会臨床的な視点からの政策(制度) 形成

・ 地域を基礎にしたより包括的な実装の必要

$\rightarrow$ 家族という関係性への社会の対応

成果(1)理論化にむけて
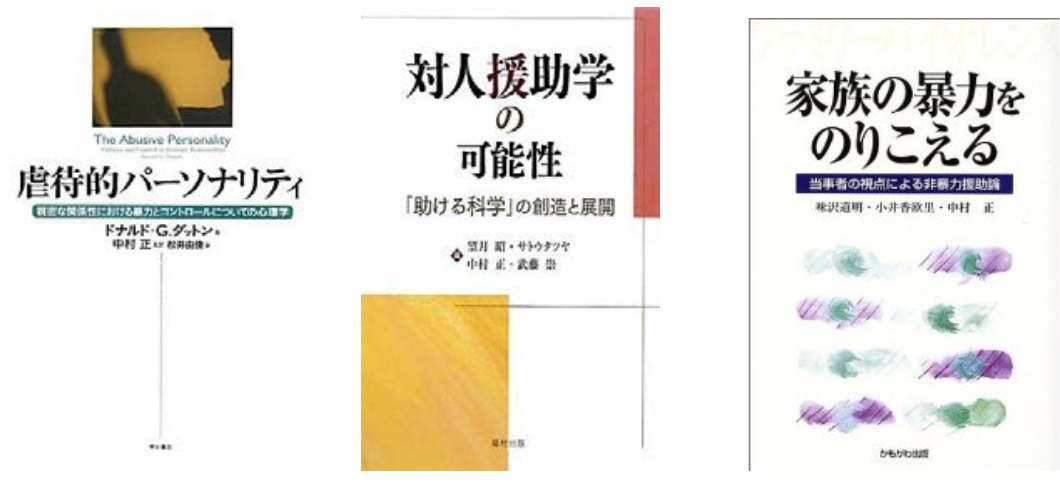
成果(2)

学会への招待と学融的な関心一概念の生成、司法臨床・治療的司法・修復的司法、 ジャスティスクライアントなど
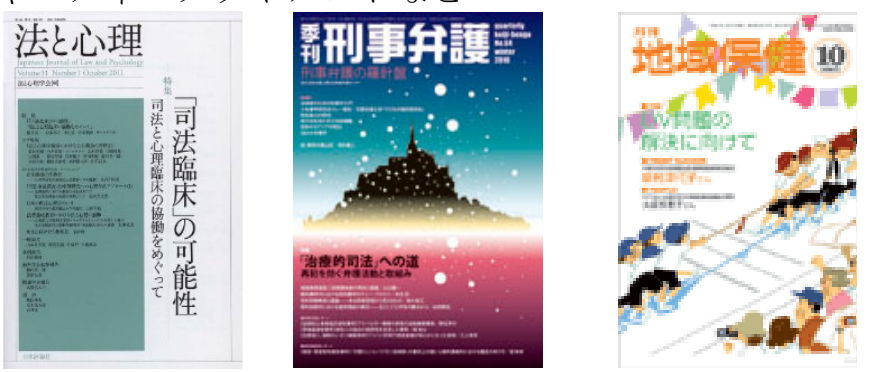

成果(3)社会への関連づけ ライフストーリワークと子どもの権利

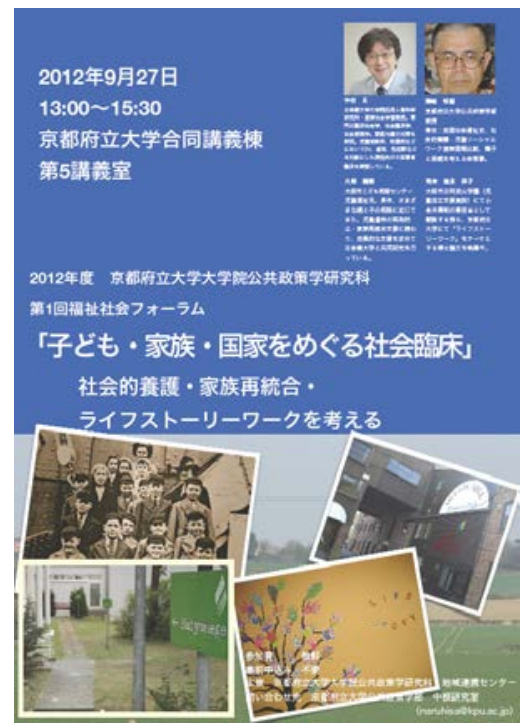

成果(4)実装継続のための拠点形成へ

立命䬺グロ一ハル・イノベーション研究機構(R-GIRO)
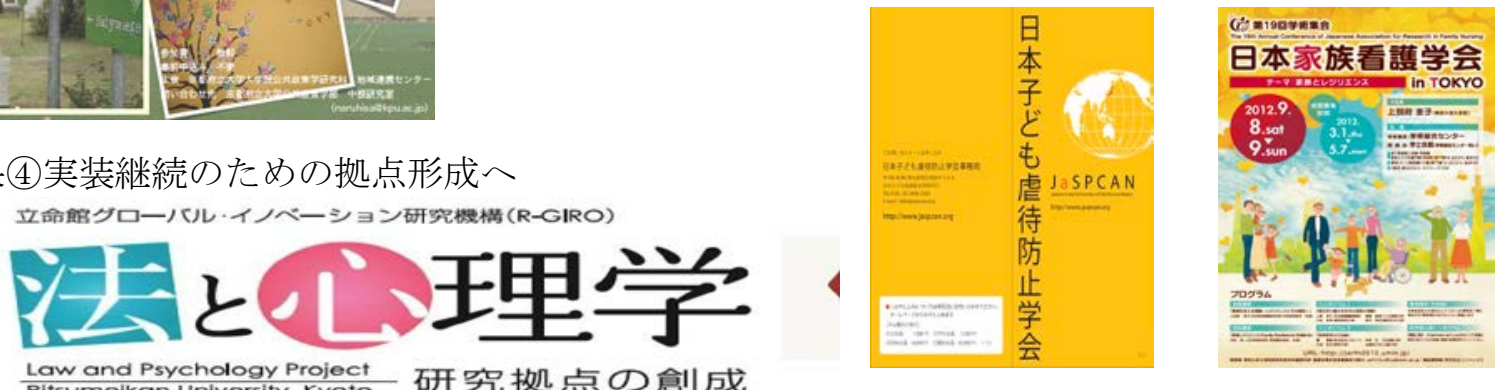

立命館大学人間科学研究所十「法心理・司法臨床センター」へ（2013 年度より 5 年間） 十科研費基盤研究（2012 年度から 3 年間）

課題(1)アプローチの手法の洗練

(1)子どものケア（きょうだい関係も視野に）

(2)親への対応（父親と母親）

(3)グループと個人と夫婦と家族面接 $=$ 多軸的 
(4)リスクーニーズーレスポンシビティＲＮRモデル

(5)Good Lives Model（G L M）の活用

課題(2)男親塾での評価指標の開発

(1)文脈構成／語彙と発話／応答する／感受する／

$\rightarrow$ エピソード抽出と語りの質

(2)説明＝中和化、否認、合理化、謝罪、被害者非難

$\rightarrow$ 言説分析

(3)定義の変更＝例 : 認知の歪み $\rightarrow$ 都合のよい考え方 お父さん子育て教室 $\rightarrow$ 男親塾

$\rightarrow$ 状況理解と自己理解

虐待親のスキーマ理解

課題(3)暴力の文化と社会を生きている

Vitality（生命力） $\rightarrow$ vie（生きること）

(1)Violence 親密な関係性において

(2)Abuse 虐待=暴力の乱用

(3)Neglect 無視・放置

(4)Bullying 弱者いじめ:「死ね」といわれるつらさ

(5)Harassment 苦しめること・悩ませること・迷惑行為

(6)Stalking 執拗な追跡行為

課題(4)広がりへの対応

高齢者虐待、ドメスティックバイオレンス加害者、いじめ、ハラスメント
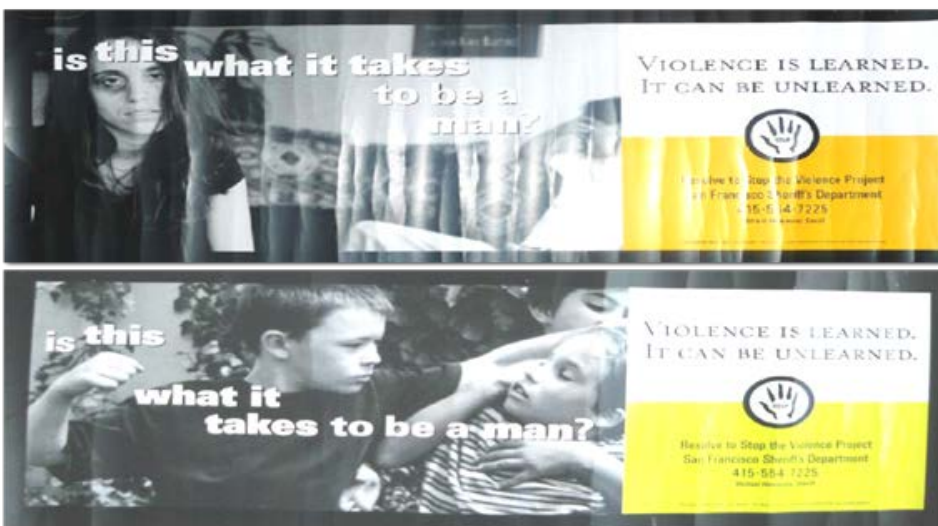

課題(5)支援・相談の整理 四つの顔
(1)チョイス
choice
「選択肢」
(2)エンパワメント empowerment 「可能性」
(3)アシスト
assist
(4)アドボカシー advocacy
「添え木」
「環境」 


\section{冢庭内虐待の特程}

\section{(1) ケアとサービスへの期待}

ドメスティックサービスへの期待

2. ヨントロールする欲求

支配する・思い通りになる・パワー感覚

(3) インティマシーへの感情 依存する心性・承認の欲望

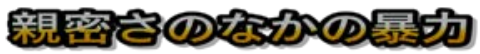

(1) 思春期・青年期暴力

(2) 子ども虐待

(3) 配偶者間暴力

(4) 高齢者虐待

(5) きょうだい間暴力

(6) 恋人同士の暴力

軳 国

(1) 家庭内暴力犯罪法 念図

(2) 接近禁止命令

(3) 加害者への対応

社会奉仕

○プログラム受講命令

相談委託

\section{『4界}

\section{局以的的}

(1) 積極的逮捕政策 (ゼロトレランス政策)

(2) 接近禁止命令

(3) DVコール、DV裁判所

(4) ダイバージョンプログラム

○加害者更生プログラム

・バタラーズプログラム
（1) 保護命令制度

(2) 賦課事項・遵守事項・指示事項

（3）加害者更生プログラム参加

- 社会的トレーニング

・再社会化プログラム 

(1) 家庭内暴力の重罰化
(2) 司法上の監督制度 (保護命令)
(3) 既存の刑罰法令に従う

(1) 虐待禁止命令・占有命令

(2) 嫌がらせ行為差し止め命令

(3) 社会更生命令

(加害者更生プログラム受講命令)

\section{台溜}

(1) 独自の「家庭内暴力罪」

(2) 保護命令

- 通常保護命令と一時保護命令

(3) 加害者処遇計画
○薬物禁絶治療
- 精神治療
○ 心理治療 (プログラム受講)

参考 :

「社会臨床の視界」を連載中

対人援助学マガジン 検索 